\title{
The Intangible Cultural Landscape of the Banda Primitiva de Llíria
}

\author{
Virginia Santamarina-Campos $\left(\mathbb{D}\right.$, José Luis Gasent-Blesa $\mathbb{D}^{\circ}$, \\ Pau Alcocer-Torres, and $\mathrm{M}^{\mathbf{a}}$ Ángeles Carabal-Montagud $\mathbb{D}$
}

\section{Introduction: Popular Music Tradition as Intangible and Creative Cultural Heritage}

The first references to ethnographic and ethnological heritage in the general norms of cultural heritage in Spain appear in Spanish Royal Decree-Law, dated 9 August 1926, which mentions its typical and picturesque character, and in the Spanish Law on the Defence, Conservation and Enhancement of National Historical-artistic Heritage, of 13 May 1933, which refers to picturesque places that must be preserved. It is not until the Spanish decrees of 1953 and 1961 that the term "ethnological" is used for the first time in terms of cultural heritage, providing an initial approach to the concept of intangible heritage related to the traditional and popular and associating it with folklore. Yet it was not until the 1978 Spanish Constitution that a conceptual framework was provided for intangible heritage, which proved to be a pioneering concept in the European constitutional context.

In the 1985 Spanish Historical Heritage Law, an important advance was perceived in the definition of ethnographic and ethnological heritage, taking in current phenomena and considering other types of goods that do not have to be material, and although there continues to be a relationship between the "ethnological" and the "traditional", traditional culture does not have to refer to the past.

In 1989, for the first time, the UNESCO mentioned intangible and intangible assets in the Recommendation on the Safeguarding of Traditional and Popular Culture

\footnotetext{
V. Santamarina-Campos ( $\otimes) \cdot$ M. Á. Carabal-Montagud

Universitat Politècnica de València, Valencia, Spain

e-mail: virsanca@upv.es

J. L. Gasent-Blesa

Universitat de València, Valencia, Spain

P. Alcocer-Torres

Colegio Helios, Valencia, Spain

(C) The Author(s) 2021

B. de-Miguel-Molina et al. (eds.), Music as Intangible

Cultural Heritage, SpringerBriefs in Economics,

https://doi.org/10.1007/978-3-030-76882-9_6
}

69 
(UNESCO, 1989), moving towards the recognition of other forms and categories of heritage, indicating that "Traditional and popular is part of the universal heritage of humanity and is a powerful means of rapprochement between existing peoples and social groups and the affirmation of their cultural identity" (UNESCO, 1989). In addition, the Recommendation defined traditional and popular culture as the "set of creations that emanate from a cultural community based on tradition, expressed by a group or by individuals, and that recognise that they respond to the expectations of the community regarding the expression of their cultural and social identity; norms and values are transmitted orally, by imitation or in other ways. Its forms include, among others, language, literature, music, dance, games, mythology, rites, customs, crafts, architecture and other arts" (UNESCO, 1989).

It was not until 1997 when a further step was taken in the International Consultation on the Preservation of Popular Cultural Spaces (UNESCO, 1998), organised in Marrakech by the Division of Cultural Heritage and the Moroccan National Commission for UNESCO, in which the distinction of Oral and Intangible Heritage was made as the heritage of humanity. Despite this progress, in the new additions to the list of world heritage sites, the materialistic and monumental vision has continued to prevail, with non-material heritage forms being relegated. In 2001, for the first time, 19 spaces and relevant forms of expression were declared Masterpieces of the Oral and Intangible Heritage of Humanity (UNESCO, 2001). The programme concluded in 2006 with the entry into force of the Convention for the Safeguarding of the Intangible Cultural Heritage (UNESCO, 2003), which was ratified in Spain in 2007, becoming part of its internal legal system. Thus, in 2008, the new Representative List of the Intangible Cultural Heritage of Humanity (UNESCO, 2008) was created, bringing together the 90 elements declared masterpieces of oral and intangible heritage in 2001, 2003 and 2005.

Spanish legislation accompanied the advances made at international level in the National Plan for the Safeguarding of Intangible Cultural Heritage, which was approved in 2011 (Ministerio de Cultura y Deporte, 2011) and in Law 10/2015, of 26 May 2015, for the Safeguarding of Intangible Cultural Heritage. In the case of the Valencian Region, its exclusive powers in terms of Valencian Cultural Heritage were implemented via Valencian Regional Government Law 4/1998, of 11 June, on Valencian Cultural Heritage (Generalitat Valenciana, 1998), which established the inclusion of ethnological heritage's intangible assets as an instrument for the protection of intangible cultural heritage, the values of which must be specially preserved and known, in the General Inventory of Valencian Cultural Heritage.

In this framework, Valencian popular musical tradition materialised by musical societies (Bands in the Valencian Region) was declared as an Intangible Asset of Local Relevance in 2011 and was included in the General Inventory of Valencian Cultural Heritage (Generalitat Valenciana, 2011). Later, in May 2018, the popular musical tradition of the Valencian Region was declared as an Asset of Intangible Cultural Interest (Generalitat Valenciana, 2018). This brought the Banda Primitiva de Llíria under the protection and safeguarding umbrella that is specified in the following measures (Generalitat Valenciana, 2018): 
(a) To carry out identification, description, research, study and documentation tasks with scientific criteria.

(b) To incorporate the available testimonies into material supports that guarantee their protection and preservation.

(c) To ensure the normal development and survival of this cultural manifestation, as well as to protect the conservation of its traditional values and their transmission to future generations.

In addition, recently, the musical societies of the Valencian Community have been declared a Representative Manifestation of the Intangible Cultural Heritage in Spain, recognising the patrimonial value of the movement of the musical societies that make up the Valencian Community (FSMCV 2021a).

On the other hand, it is important to note that, in 2019, Llíria was declared as a UNESCO City of Music under the broader Creative Cities Network (UNESCO, 2019), recognising a long musical history that dates back to the third century BC, and confirming that music constitutes a fundamental part of the town's cultural identity. The UNESCO Creative Cities Network was created in 2004 with the aim of promoting cooperation between cities that identify creativity as a strategic factor for sustainable urban development. Currently, the 246 cities that make up the Network work together with the aim of positioning creativity and cultural industries at the centre of their local development plans (UNESCO, 2020).

\section{Methodological Approach}

A qualitative research method was used to develop the work mainly focusing on documentary and field research. The study of documentary sources included the analysis of bibliographic sources, and especially archive research, mainly the Banda Primitiva de Llíria's Archive, the Ateneo Musical y de Enseñanza Banda Primitiva de Llíria (Music and Teaching Athenaeum of the Banda Primitiva de Llíria), and the Miguel Blat Ibáñez Collection at the Valencian Institute of Culture (IVC) of the Valencian Regional Government. On the other hand, the fieldwork focused on the use of tools such as participant observation and semi-guided interviews.

\section{Challenges of the Popular Music Tradition in Llíria}

In the specific case of the Valencian Region, the musical phenomenon of bands has been a key part of the associative framework of the territory (Asensi Silvestre, 2008). The Valencian Region enjoys a long musical tradition which, through its municipal bands and music schools, trains over 60,000 students, giving rise to 1,100 bands, which bring together around 40,000 musicians in 500 musical societies, representing half of those existing in Spain (Cultural València, 2018; SGAE, 2020). These bands 
play a fundamental role in supporting most of the traditions and popular festivals in the Valencian Region, in which musical works or songs which are not their own are used, such as the pasodobles in the Fallas festival in Valencia, or in works that are created especially, as is the case of the compositions for the Moors and Christians festivals, which annually premiere pasodobles and Moorish and Christian marches (Bottle Nicolás, 2019). In addition, it should be noted that bands are present in $95 \%$ of the municipalities with more than 500 inhabitants, contributing around $€ 40$ million to regional GDP (Cultural València, 2018). The crisis derived from COVID19 has significantly affected the Valencian Region's musical societies, which suffered estimated economic losses of about $€ 20$ million in 2020 (SGAE, 2020). From a social point of view, the pandemic has constituted a framework to reaffirm and reinforce the importance of the social function of bands, which was showcased in the \#WindowsOfMusicAndHope campaign on social networks, which aimed to spread a message of hope and at the same time to raise awareness about the importance of staying at home. In this new uncertain environment, music has been a way to unite people and help them overcome the difficulties they face due to social distancing measures (UNESCO, 2019), once again demonstrating its ability to mobilise and encourage new recruits, even in new cultural environments such as social networks.

The choice of the town of Llíria is justified because of its strong musical society culture which has been in existence since the nineteenth century. At that time, this civic band phenomenon was represented in the town by the musical groups of Música Vella (old music) or Primitiva and Música Nova (new music), the latter formed in the middle of the nineteenth century by a split from the Música Vella, but which disappeared at the end of the nineteenth century (Martín Montañés, 1994). At the beginning of the twentieth century, rivalry began between the Banda Primitiva and the new ensemble Unió Musical, serving as a vehicle for cultural transmission and at the same time configuring a fragmented local identity due to the artistic rivalry between the two (Asensi Silvestre, 2008).

The history of Llíria has been linked to tradition and band rivalry since the nineteenth century, and the town cannot currently be understood without them, as Llíria would be completely different (Informant 2). The existing musical rivalry in Llíria is also evident in the urban framework itself, where a street and commemorative plaques mark the division between the two areas of the bands, delimiting cultural and religious spaces. Thus, the Raval neighbourhood and the church of St Francis of Assisi are reserved for the Banda Primitiva, and the old town next to the church of Our Lady of Remedies is for the Unió Musical band (Informant 2).

On the other hand, in the specific case of the Banda Primitiva de Llíria, the musical society culture has reinforced the deeply rooted ideas and feelings of identity among the town's inhabitants that are part of this culture, to the point of linking their demonym with their belonging to said band (Informant 2).

For these reasons and following the guidelines of the Convention for the Safeguarding of Intangible Cultural Heritage (UNESCO, 2003), this work aims to support the safeguarding, respect and awareness at local, national and international level of the Banda Primitiva de Llíria, and the enhancement of one of the oldest civic bands in Spain (Banda Primitiva de Llíria, 2009a), with the aim of encouraging local, national 
and international dialogue centred on promoting cooperation between musical societies. The objective is to provide greater visibility and create positive recognition of the fundamental importance of this form of heritage for social cohesion and development, in an environment that has been transformed into one of collective action, solidarity, shared culture and creativity (Rausell Köster, 2013).

It is remarkable that the term civic band includes the amateur band (also known as community band) and the professional band (Rodríguez Lorenzo, 2014).

\section{Historical Contextualisation of Llíria}

Llíria is located in the northwest of the province of Valencia and is $25 \mathrm{~km}$ from the city of Valencia. It is the capital of the Camp de Turia area. Its municipal district has an extension of $229.82 \mathrm{~km}^{2}$ and is one of the largest in the Valencian Region. It has a contrasting landscape between a mountainous area which marks the start of the Sierra Calderona and an orchard area on the left bank of the River Turia (Ayuntamiento de Llíria, 2020a). In the last official population census published by the National Institute of Statistics, Llíria had a population of 23,482 inhabitants (INE, 2020).

Llíria is a city with an extensive cultural heritage. On the one hand, it has a long musical tradition, playing host to musical societies whose musicians and board members receive no financial compensation for their work. These societies are the Banda Primitiva, the Unió Musical, the Orquesta de Plectro "El Micalet", the Agrupación Musical Edetana "Vicente Giménez" and the Banda Musical Unión Democrática de Pensionistas (Ayuntamiento de Llíria, 2019). Both the Banda Primitiva and the Unió Musical are famous for the numerous domestic and international awards they have received (Ayuntamiento de Llíria, 2020b). In addition, the town houses one of the most significant archaeological and monumental complexes in the entire Valencian Region (Ayuntamiento de Llíria, 2020b). The oldest remains in the municipality of Llíria date back to the late Upper Paleolithic. In the Eneolithic period, there was an important town on the edge of the Rambla Castellarda (Bonet Rosado et al., 2014), which seems to have lasted until the early Bronze Age. Remains from this age have been found in the Torreta and the Cova del Cavall (Donat Zopo \& Gascó Martínez, 1973), and several settlements in Castillarejo de Peñarroya, in Lloma del Camí del Cavall, in Tossal de San Miguel (Saint Michael's Hill) and in Cova Foradà, all of which were occupied later during the Iberian period and even during Roman rule. The last two periods are especially important, and the town has been declared a Site of Cultural Interest.

As already mentioned, the current city of Llíria has its roots in the Bronze Age, in the establishment there was on the Saint Michael's Hill towards the middle of the second millennium BC (Hermosilla Pla, 2011e). This was continued in the Iberian town of Edeta, which was the capital of Edetania. Two other Iberian villages are also located in the municipality of Llíria: La Monravana and El Castellet de Bernabé (Rosado et al., 2008). Its political and economic importance, as well as its strategic position, led it to play an important role in the Roman civil wars. In Roman times, 
because of its desire to remain faithful to the Republican faction, it was destroyed by Sertorio's troops in $76 \mathrm{BC}$, which is why its inhabitants moved to the plain and built a new city with entirely Roman features (Pla de l'Arc settlement). The city of Edeta-Lauro was of paramount importance during the first and second centuries, while the decline that began in the third century and was accentuated in subsequent centuries could have been a parallel consequence of the growth of Valentia (today Valencia) (Hermosilla Pla, 2011e). It is important to highlight that in the Iberian culture, Edeta, as the town was known during that period, already had a strong link with music, as reflected in the ceramics of Saint Michael's Hill, with some of the best known representing Iberian images of individuals playing musical instruments (Cardiel, 2017).

During the Visigothic period, the Roman baths of Mura (Tormo-Esteve, 2018) were reused as a Christian monastery, although during the seventh century the Pla de l'Arc settlement, where the baths were located, was completely abandoned. In the Muslim period, the town was the residential headquarters of the Qadi, a kind of Muslim judge or magistrate appointed directly by the caliph.

In the year 1090, El Cid besieged the city, but left the site without taking it after the Queen Constanza, wife of Alfonso VI, required his help to fight the Almoravids in Andalusia (Hermosilla Pla, 2011c).

James I of Aragon took the city that lived under Muslim rule in 1238 and gave it to the Infante Fernando. Although Llíria was always a royal town, it had several manors such as that of María Fernández in 1293 and of the Infante Juan from 1337. The expulsion of the Moriscos in 1609 did not dramatically affect the town since it had a population of old Christians mostly (Hermosilla Pla, 2011d).

In 1707, King Felipe V created the Duchy of Llíria to reward the services of the Duke of Berwick, who was victorious in the Battle of Almansa (War of Succession), and granted it to him. The first duke, James Fitz-James Stuart, was the son of James II, King of England. He was Marshal of France and Captain General of Spain during the War of Succession. The third Duke of Llíria, Jacobo Felipe Fitz-James Stuart y Silva, married María Teresa de Silva y Haro, Duchess of Alba. From this moment on, the title of Duke of Llíria passed into the hands of the House of Alba (Hermosilla Pla, 2011d).

During the eighteenth century, the physiocratic policy of the Bourbons gave rise to spectacular advances in the agriculture in the town. In later times, during the War of Independence, the population abandoned the urban area and took refuge in the mountains. The French troops occupied the town from 1810 to 1813 and made forts in the sanctuary of Saint Michael (Saint Michael's Hill). Llíria was sacked during the Civil War of 1836 by the Carlist troops of General Cabrera on numerous occasions. In 1887, by royal decree, Llíria was granted the title of city. It should be remembered that the historical events of the time are fundamental to understand the development of the Banda Primitiva, since it is closely linked to the events that took place in the turbulent nineteenth century. An example of this is the obvious connection between the Napoleonic occupation and the process of ecclesiastical confiscation in the creation of the Banda Primitiva (Hermosilla Pla, 2011a). 


\section{Origin of the Banda Primitiva de Llíria}

The Ateneo Musical y de Enseñanza Banda Primitiva de Llíria has its headquarters in Llíria, located in the historic Raval neighbourhood, in the northwest of the town. The origins of this musical society date back to 1819 , a date that is taken as a reference and the reason for celebrating its 200th anniversary in 2019. This date has been mentioned by authors such as Domingo Uriel (Uriel, 1946), Salvador Seguí (in Badenes Masó, 1992), Roberto Martín Montañés (Martín Montañés, 1994), Vicente Galbís (in Casares Rodicio, 2006) and Juan José Llimerá (in Hermosilla Pla, 2011b). However, there is evidence that there were musical groups in Llíria from the middle of the eighteenth century onwards, and at the beginning of the nineteenth century, there was also "Military Music" and a "Chapel of Music" (Martín Montañés, 1994).

As for the origins of the Banda Primitiva, there are two documentary references from 1822 detailing the hiring of a musical group for religious events, i.e. street processions. These two historical documents are the Libro de Deliberaciones de la Venerable Orden Tercera del Carmen de la Villa de Liria (Book of Deliberations of the Venerable Third Order of Carmen of the Town of Llíria) (Orden del Carmen, 1822) and the Libro de Entradas y Salidas del Convento de San Francisco (Doubleentry bookkeeping of the Convent of Saint Francis) (Orden Franciscana, 1821-1835). The first book details the cost of hiring "music" in mid-1822, this being equivalent to a musical group, and with the textual reference of "Música de bombo/Música del bombo" (i.e. bass drum music), to clearly differentiate it from chapel music, which was linked to the Parish Church of the Assumption (Asensi Silvestre, 2008; Llimerá in Hermosilla Pla, 2011b; Martín Montañés, 1994). On the other hand, the second document, linked to the old Saint Francis Convent, collects the oldest reference found so far of payment for the "music" (i.e. for the musical group) that dates back to March 1822 , as well as other references from that same year for processions, such as the Easter procession and the reference to the procession of the Immaculate Conception, deeply rooted in the Raval neighbourhood or "Vila nova" (new town). This payment to the musical group was made periodically in subsequent years, for instance, on the occasion of Easter and Corpus Christi processions. It should be noted that the Libro de Entradas y Salidas del Convento de San Francisco prior to September 1821 has not been located, so it is unknown if there are previous references.

The relationship between Franciscan convents and the appearance of instrumental musical groups is a phenomenon that also occurred in other towns in the Valencian Region (Pérez-Jorge, 1951; Redacció ARA Multimèdia, 2013). This religious order did not have a chapel of musicians in their convents' churches, since its rules only contemplated singing in the Liturgy of the Hours. Then, it is reasonable to assert that this link may have been strengthened by the fact that they somehow promoted the development of musical groups by teaching music (Redacció ARA Multimèdia, 2013) and hiring the groups mainly for processions and other types of popular and religious acts related to the convent. 
In the case of the Banda Primitiva, it was the Franciscan father Antoni Albarracín Enguídanos who promoted this initial seed documented at the beginning of the nineteenth century, mainly linked to the Franciscan convent of Llíria and centring above all on what we could call "Música de calle" (street music) or "Música del bombo" ("Bass drum music"), as mentioned above and which has lasted until today.

Based on the documents mentioned above, the first known performance of this group was registered in the first quarter of 1822. Therefore, its origin would have been a few years before that date, due to the time needed for the group to purchase the instruments required for playing and, mainly, to train the future musicians. This is probably the reason why the tradition takes 1819 as the beginning of this musical training, and why this year has been used by different authors as the starting date of the ensemble, e.g. Martín Montañés (1994).

This musical group continued its development in subsequent years, and it is in 1846 that it appears with the name of "Música Vella" (old music), as a result of the split of some of its members who formed a new group, the "Música Nova" (new music), as mentioned above. From 1848 onwards, the Música Vella became a full organised musical society that was governed by a Board headed by a Chairman.

In 1858, this Society appears under the name of "Banda Primitiva", also popularly known as the Clarín (Image 1), which maintains all the social and artistic heritage of the previous group (Llimerá Dus, 2011). Great musical artists have come out of this group, mainly in Spain and Europe including composers, conductors, instrumentalists and teachers in music schools, secondary schools and universities (Torres Castellano, 2006).

Currently, the society has over 1,000 members and develops its cultural activities through the different groups that make it up: the band, the youth band, the symphony orchestra, the choir and the theatre group, in addition to a music school that feeds all the society's groups.

\section{Background of the Banda Primitiva de Llíria}

The Banda Primitiva de Llíria is not only one of the oldest civic bands in Spain, but it is also one of the musical groups that have won the greatest number of awards in Europe. It is important to highlight that the Banda Primitiva won the first prize in the first Valencia community band contest in 1888 (Astruells Moreno, 2017) and it is the only one that has won this award in three consecutive centuries (Pelechà and Francés, 2016). It competes in the contest's highest category (Image 2), with over 30 first prizes and several honourable mentions, and its competitive spirit is one of the key factors of the band's resilience. Its ability to adapt and obtain positive results in the face of adverse situations is linked to the incentive effect that the competitive model of contests involves as they generate a whole system of rewards and moral incentives that encourage effort, as indicated by one of the society's members "everything that is not winning is losing. Going to a contest and finishing second is an absolute 


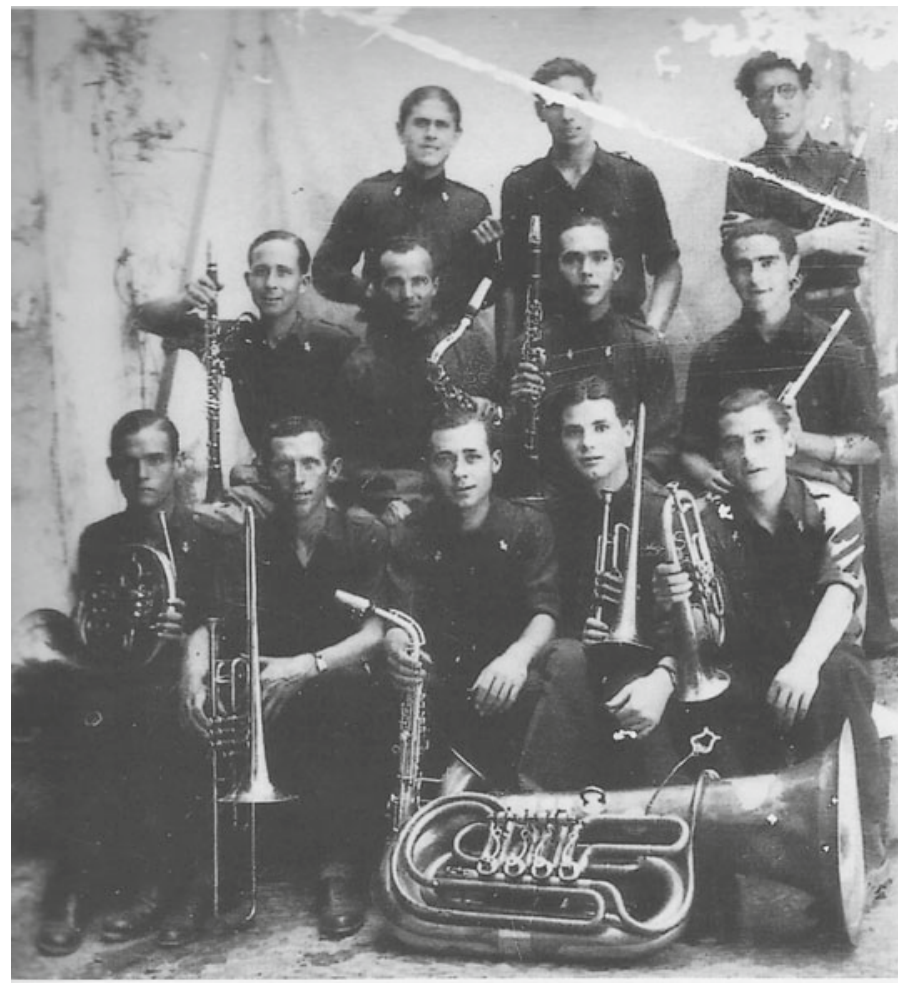

Image 1 Group of Banda Primitiva musicians in the 1940s. Source Banda Primitiva de Llíria Archive, with permission

failure" (Informant 2). The most outstanding awards include (Banda Primitiva de Llíria, 2009b):

- The Gold Medal of the City of Llíria, awarded in 1962.

- The Gold Medal of the City of Kerkrade in the Netherlands, awarded in 1962.

- The Golden Trumpet of the Czechoslovak embassy in the Netherlands, awarded in 1966.

- The Gold Medal and Flag of the City of Kerkrade, awarded in 1966.

- The Silver Medal awarded by the Governor of Edinburgh in 1966.

- The Third Millennium Academy Award granted by the World Academy of Sciences, Technology, Education and Humanities in 2005.

- The 2012 Valencian Region Cultural Merit Medal, a distinction awarded annually by the Valencian Government to outstanding entities and individuals in the field of culture.

Since it was founded, the Banda Primitiva de Llíria has given innumerable performances that include concerts, parades and participation in diverse cultural events (Image 3). Some of the most relevant include the 1929 International Exhibition in 


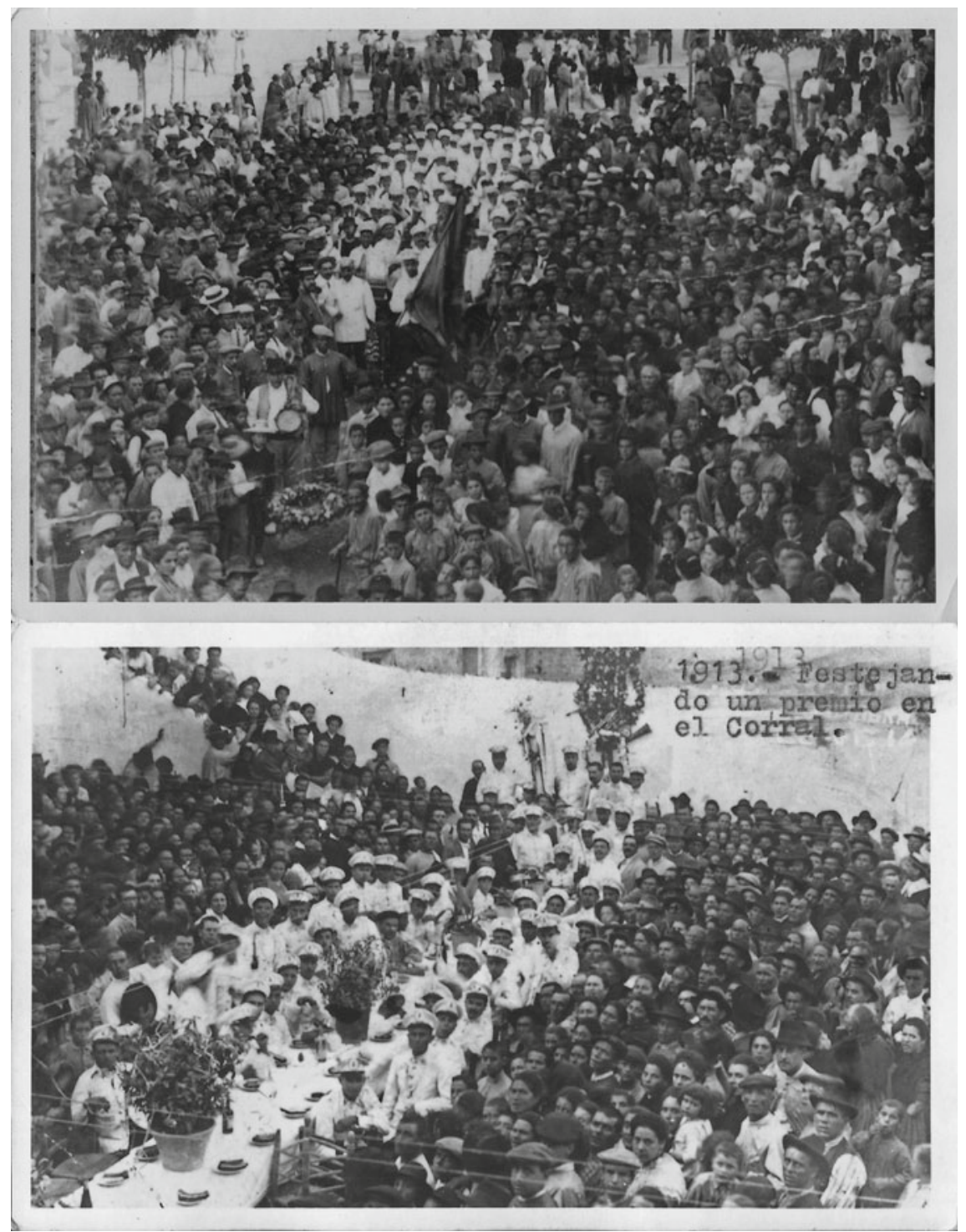

Image 2 The Banda Primitiva after the City of Valencia International Band Competition in 1913. Source Banda Primitiva de Llíria Archive, with permission

Barcelona, its 1984 performance at the Maurice Ravel Auditorium in Paris and the concert at the Municipal Theatre in Kortrijk (Belgium) to mark the 2nd WASBE World Congress. It has also performed in numerous charity events and international music promotion programmes in developing countries. 


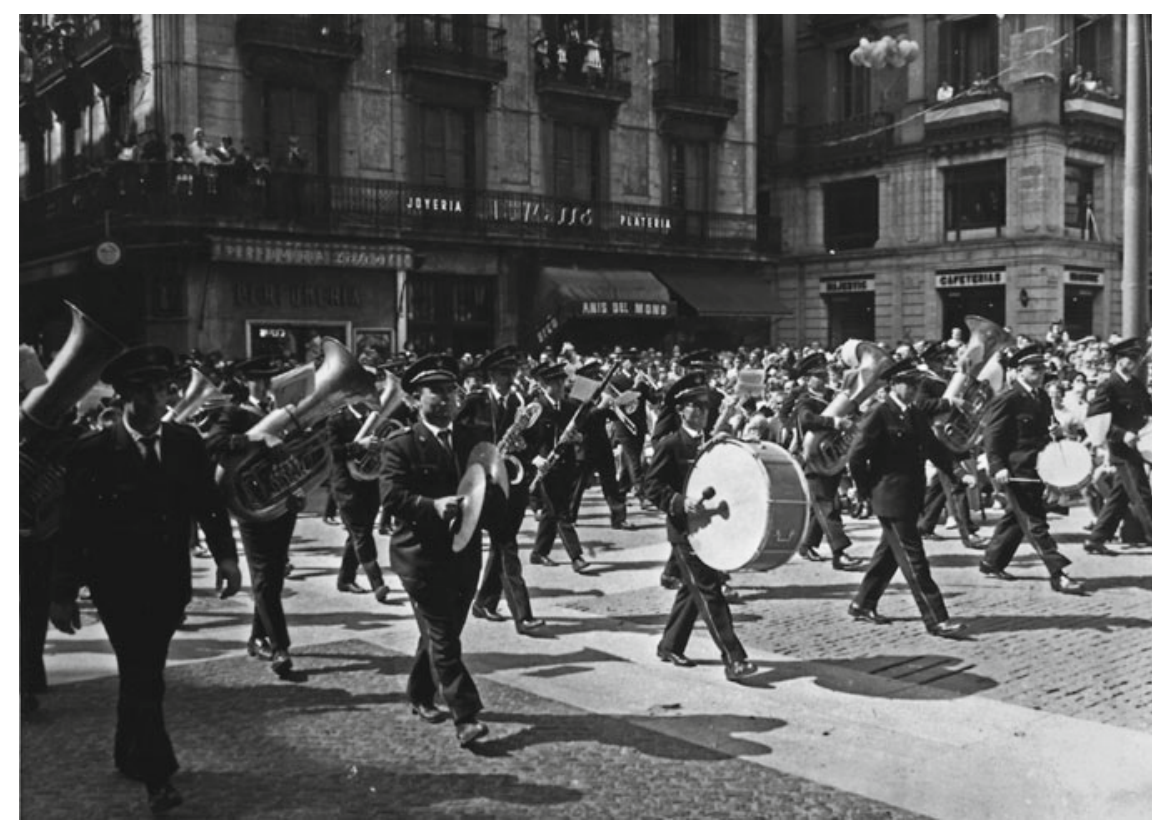

Image 3 Participation of the Banda Primitiva de Llíria in the Gracia Festival in Barcelona in the 1960s. Source Banda Primitiva de Llíria Archive, with permission

In 1976, the Banda Primitiva was hired by Spain's public television company (TVE) to perform in the programme Directísimo. In 1978, a live concert was recorded by TVE in Llíria's Main Square and another performance also took place at the Ministry of Culture Theatre in Madrid. For several years, the Banda Primitiva made recordings for the programme "Nuestras Bandas" on Valencian Television.

It has performed in practically all the main Spanish provincial capitals, as well as in various European countries, such as Germany, Belgium, France, the Netherlands and Switzerland (Banda Primitiva de Llíria, 2009b).

It was the first European band to perform in the USA, participating in the commemorative acts for Hispanic Day held in New York in October 1981 (Banda Primitiva de Llíria, 2009b). This performance had worldwide impact as it was broadcast by Univisión, TVE, RAI and other European television channels. In 1992, it returned to the USA for a tour of Los Angeles (to mark the 500th Anniversary of the Discovery of America) (Image 4). It was also the first European band to perform in China (Beijing and Shanghai) in 2004 (Banda Primitiva de Llíria, 2009b).

In addition to its principal music directors, the Banda Primitiva de Llíria has been led by some of the world's most prestigious conductors, such as Sergiu Celibidache, Desirée Dondaine, Odón Alonso, Rafael Frühbeck de Burgos, Plácido Domingo, Josep Pons, Miguel Ángel Gómez Martínez, Jan Molenaar, Manuel Galduf, Jan Cober, Luis Cobos and Rafael Sanz-Espert (Generalitat Valenciana, 


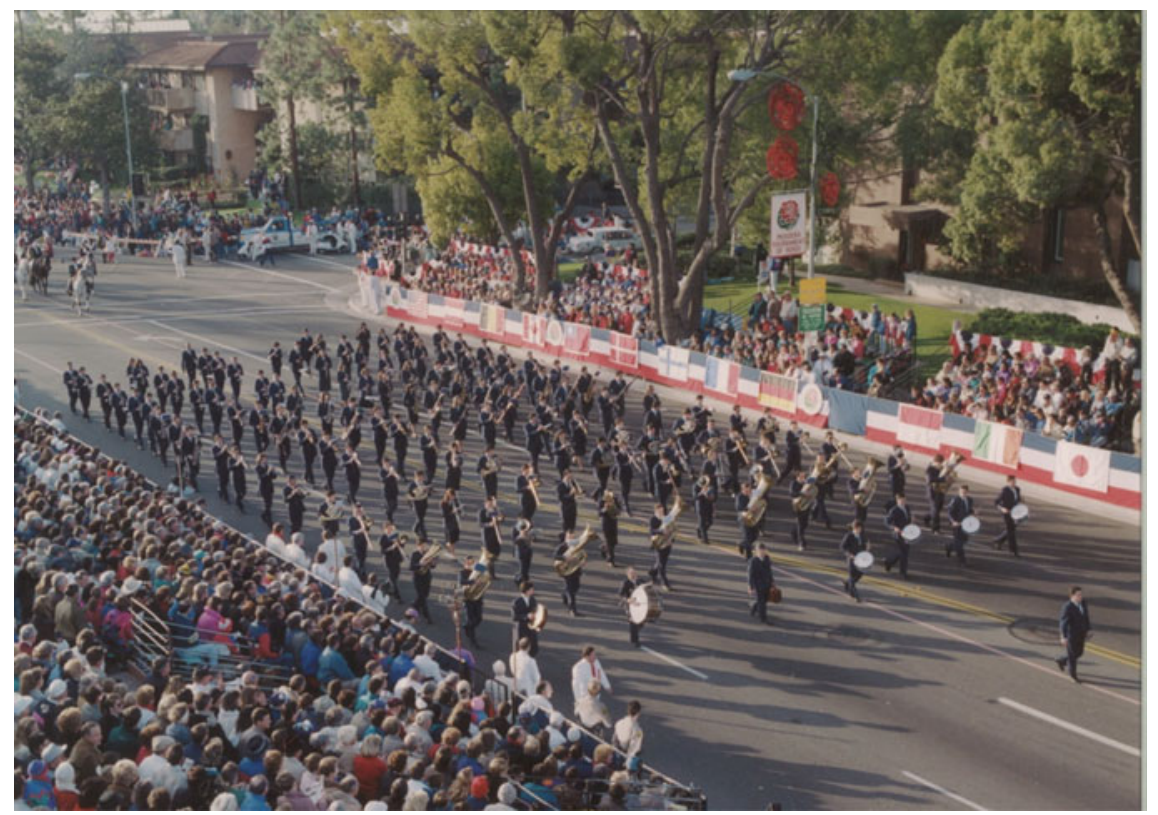

Image 4 Banda Primitiva de Llíria playing in Pasadena's Rose Parade, California (USA), 1992. Source The Banda Primitiva de Llíria Archive, with permission

2012) (Banda Primitiva de Llíria, 2009b). Since November 2013, it has been led by Javier Enguídanos Morató (Banda Primitiva de Llíria, 2009b).

The Ateneo Musical y de Enseñanza Banda Primitiva de Llíria has made more than 50 audio, video and television recordings. Its performances have been broadcast on both state and foreign radio and television programmes.

Since 2008, the Banda Primitiva has actively collaborated with UNICEF. It has been a member of the WASBE since 2010 (Banda Primitiva de Llíria, 2009c).

\section{The Banda Primitiva de Llíria as Intangible Cultural Heritage}

It is important to remember that Intangible Cultural Heritage does not imply the absence of materiality but rather the incorporation of social practices, processes, knowledge and expressions, giving more importance to processes than to objects. The Banda Primitiva de Llíria is, therefore, the sum of the immaterial through music, the material with its instruments and scores, and of the cultural spaces inherent to it, such as its theatre-concert hall (Image 5).

Thus, the band is presented as a defined resource based on its social nature, highlighting the processes of creation, diffusion and the assignment of meaning. 


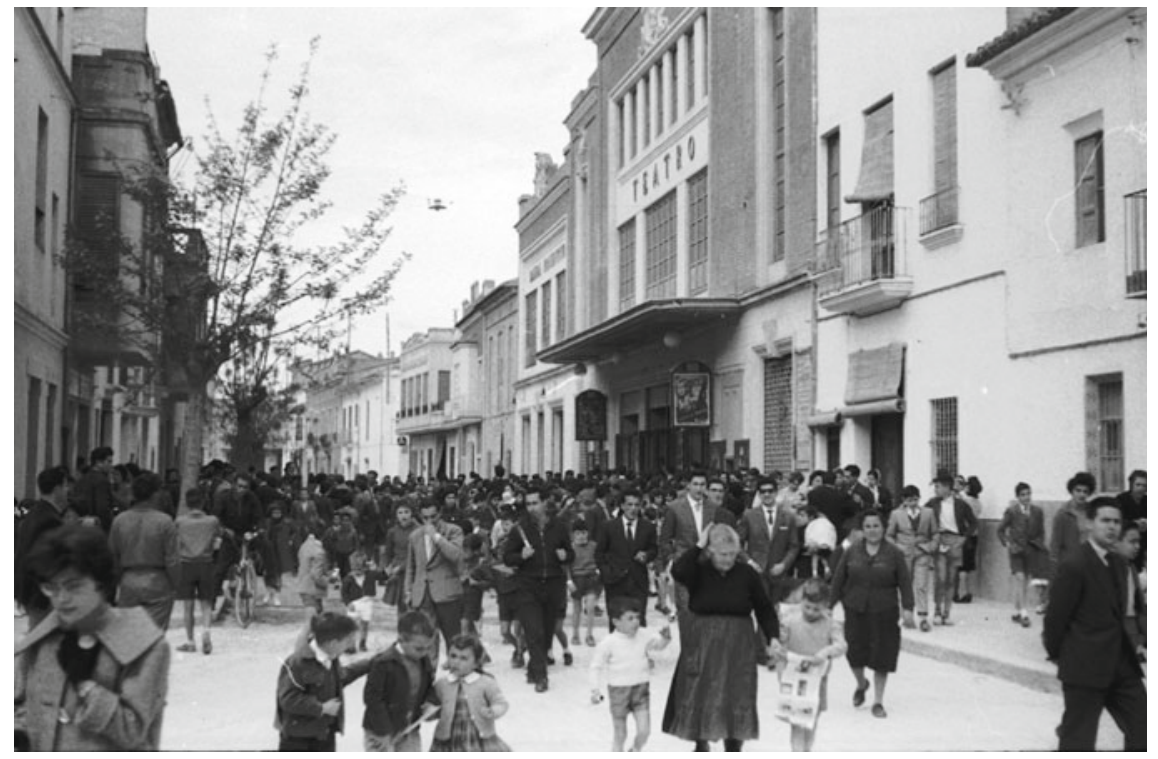

Image 5 Banda Primitiva theatre-concert hall after a film showing in the 1960s. Source Banda Primitiva de Llíria Archive, with permission

Music makes more sense in that it is used, experienced, ritualised and identified by Edetans (inhabitants of Llíria) for whom belonging to the band is part of their family heritage (Informant 1). For its almost 500 federated musicians (band, youth band and orchestra), being a member of this musical society is a privilege, due to its historical background (Informant 2) (Image 6). In addition, the Banda Primitiva is presented as an open heritage resource, whose cultural outreach transcends the physical boundaries of Llíria, and is expanding thanks to the uses and values assigned to it not only by the Llíria society, but also by musicians from other nearby towns that have joined the band.

Currently, the Banda Primitiva de Llíria's main musical groups have over 180 musicians in the concert band and 75 musicians in the symphony orchestra. These can be broken down into the following categories (FSMCV, 2021b):

(a) Professional Musicians. Around 50\% of the staff are professional musicians in various orchestras (e.g. the National Orchestra of Spain, the RTVE Symphony Orchestra, the Valencia Orchestra, the Principality of Asturias Symphony Orchestra, the Barcelona and National Orchestra of Catalonia, the Symphony Orchestra of Grand Liceo Theatre of Barcelona, the Symphony Orchestra of Bilbao, Symphony Orchestra of Castille and Leon, the Orchestra of Extremadura, the Symphony Orchestra of Madrid and the Symphony Orchestra of Malaga), professional wind bands (for example, the municipal bands of Valencia, Albacete, Alicante, Barcelona, Madrid, and Las Palmas de Gran Canaria), military bands (Band of the Royal Guard, Band of the Civil 


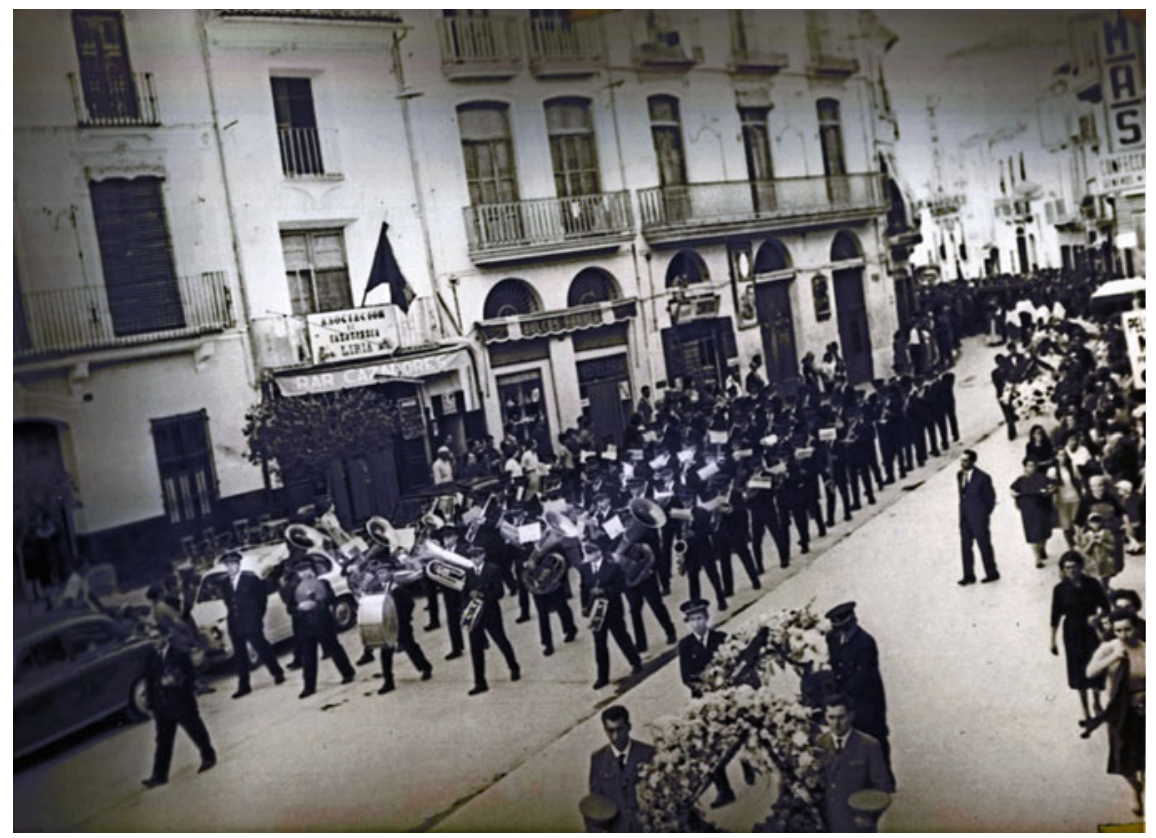

Image 6 Participation of the Banda Primitiva de Llíria in the burial of one of its members in the 1960s. Source Banda Primitiva de Llíria Archive, with permission

Guard) and as teachers in the main Spanish public music schools (e.g. the music schools in Alicante, Castellon, Valencia, Castile-La Mancha, Granada, Madrid, Galicia, Jaen, Castellon, Valencia, and in many other schools in Valencian towns and across the rest of Spain). Some members of the society are also well-known professional conductors and composers.

(b) Non-professional musicians. Around 25\% are amateur musicians who are engaged in other professional activities unrelated to music.

(c) Student musicians. Around $25 \%$ are young people who are studying music at different levels.

Sheet music is a fundamental heritage resource in a musical society. The works are usually played repeatedly or lent to other bands. The Banda Primitiva de Llíria's oldest sheet music in its archive dates back to 1917. Some sheet music may be older but has no date or signature (Informant 3) (Image 7).

The information available on these documents is the date and composer of the symphonic works. However, in most cases, the date on which they were transcribed is unknown, and the only information available is the name of the composer who wrote the work (Informant 3).

As a result of the fire that occurred in 1937 (Informants 2 and 5), the need arose to carry out an inventory of the recovered material heritage. Accordingly, in the 1950s, the archive was created to house a copy of each bought or original score that the 

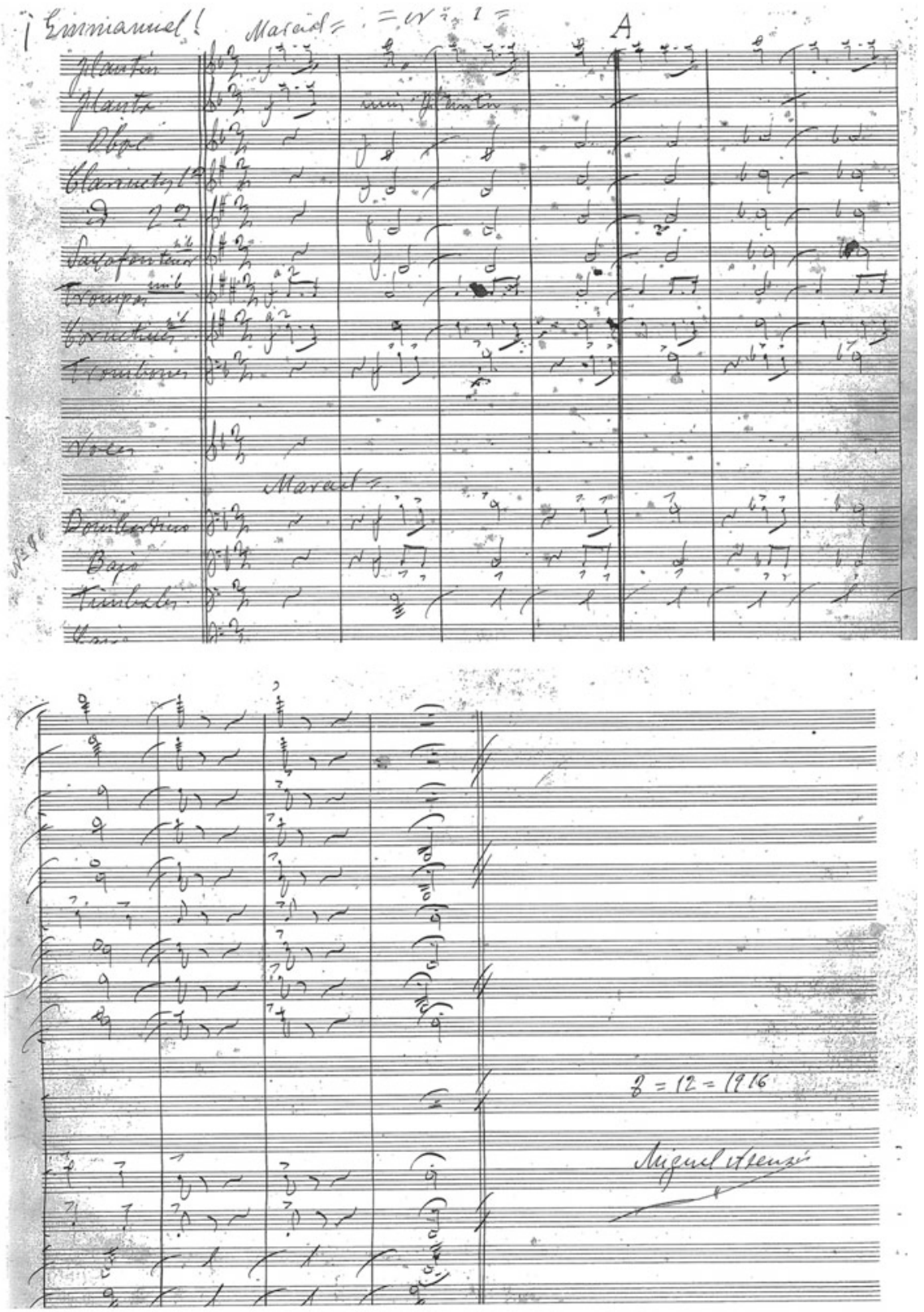

Image 7 Oldest scores belonging to the Banda Primitiva de Llíria. Source Banda Primitiva de Llíria Archive (1919), with permission 
Banda Primitiva has played. The state of conservation of the scores is good, and in 1994, the archive began to be digitalised (Informant 3).

The archive currently has 3,400 works on paper or in digital format, although after the recent discovery of new material (Informant 3), it is estimated that the archive will reach a total of 4,000 works (Informant 2). Thus, the musical society has a rich collection that includes scores for symphonic works, zarzuelas, pasodobles, procession marches and Easter marches. It should be noted that most of the works in the archive are symphonic orchestra scores which have been transcribed for concert bands, a task that was largely done by the musical director of the band at different times (Informant 3) or by donations (Informant 2). The musician who transcribed the greatest number of works was José María Malato (Image 8), the conductor of the Banda Primitiva de Llíria between 1960 and 1975, who contributed 30 works of approximately 20-30 min in length. It is important to emphasise that these works are registered in the SGAE (Informant 3) (Sanchis Rodenes \& Malato Ruiz, 2004).

In the past, playing a transcribed work was considered to be a privilege. Currently, composers write directly for the wind orchestra (i.e. the band) and more importance is given to works expressly created for this kind of ensembles (Informant 3).

Finally, the Banda Primitiva, throughout its two centuries of history, has used different cultural environments to perform its activities. In the beginning, the main stage of the band was the street, where it played behind the main social, religious and festive events that took place in the town, such as parades and processions.
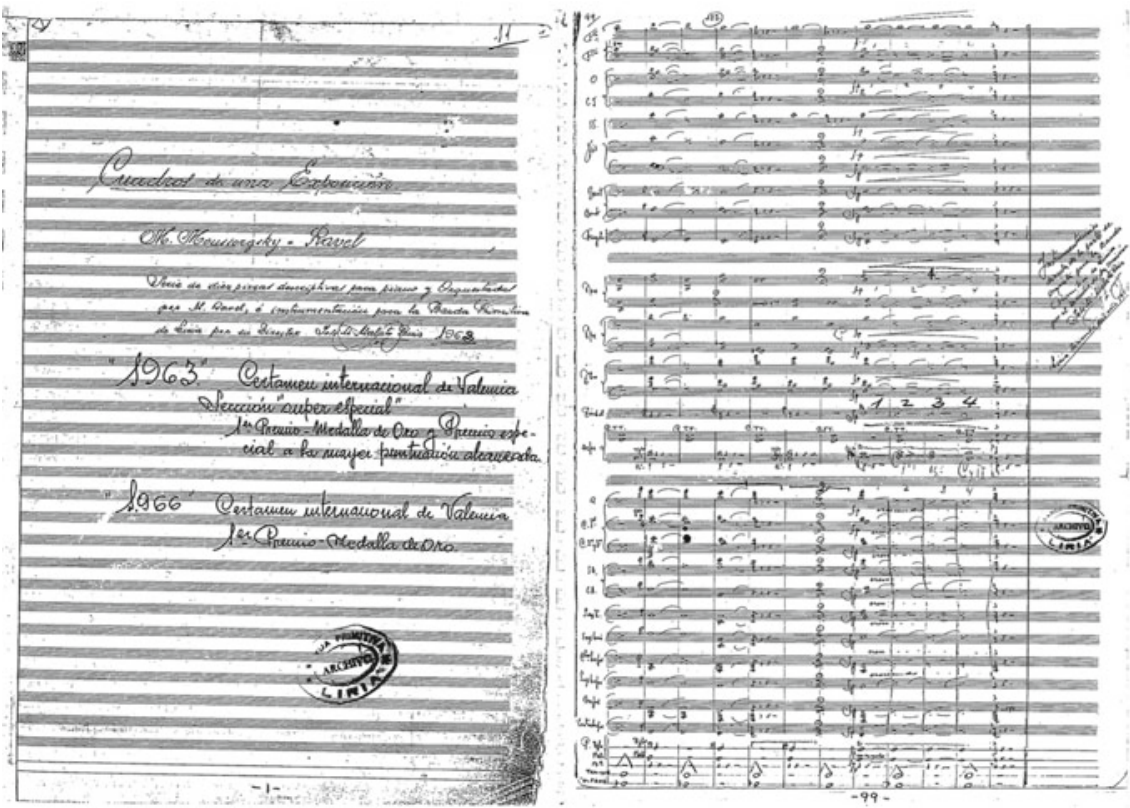

Image 8 Symphonic orchestra scores transcribed for the band by the director José María Malato in 1963 and 1966. Source Banda Primitiva de Llíria Archive (1919), with permission 
Later, different municipal and private-owned venues were used, and it was not until practically 1950 that the Banda Primitiva acquired its own facilities.

The first theatre the Banda Primitiva used, known as the Español Theatre, was not owned by the Society and dates back to approximately 1895. This theatre closed in 1904, and the band moved to the former Saint Francis convent (Duran Martinez, 1995). Around 1915, different construction and refurbishment works were carried out in the Español Theatre so that the Society could relocate there; the theatre had a capacity of about 850 seats. The musical Society leased this facility on 15-year contracts, but none were fulfilled, which infers a tense relationship between the property's ownership and the Society. In this building, the Banda Primitiva played different zarzuelas, sainetes (skits) and staged theatrical representations (Images 9 and 10), generating great cultural vibrancy in the city that led many local authors and composers to premiere their works in this theatre. These included the premiere of Emmanuel in Christmas 1916 (Diario de Valencia, 1917). Films were also screened, and important concerts and plays by renowned groups and singers of the time were staged (Martín Montañés, 1994). This situation led successive boards of directors to consider acquiring the theatre, an opportunity that arose at the end of the Civil

Image 9 Former Español Theatre programme (1941). Source Miguel Blat Ibáñez Collection, IVC Musical Documentation Centre, with permission

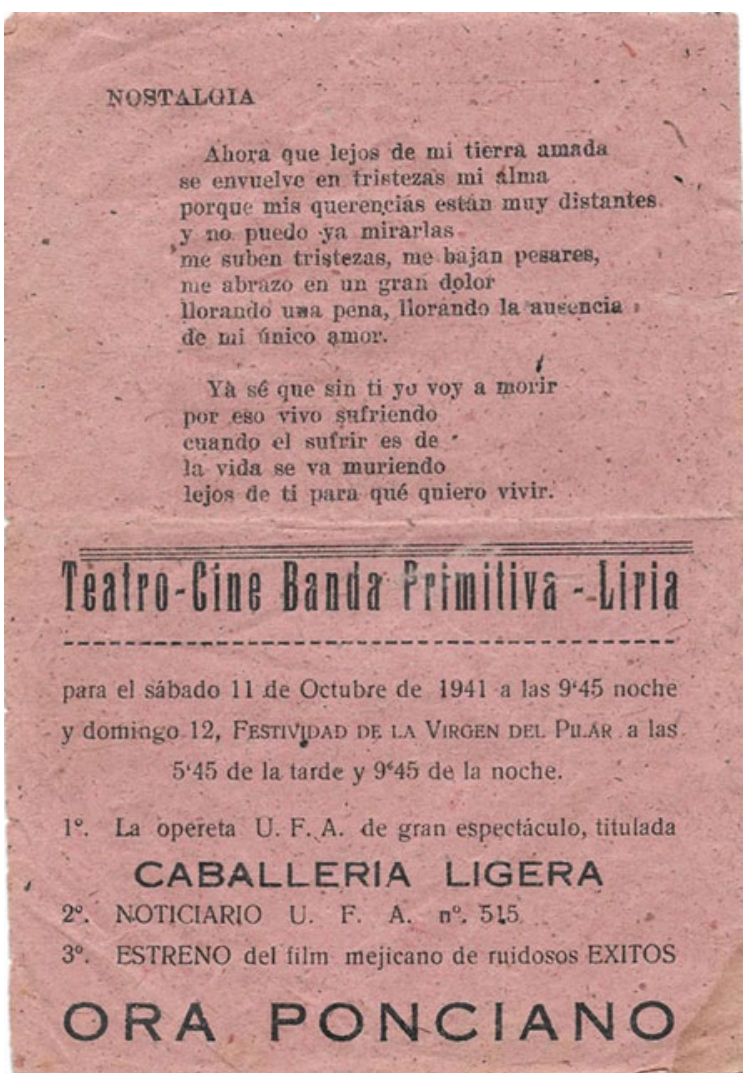




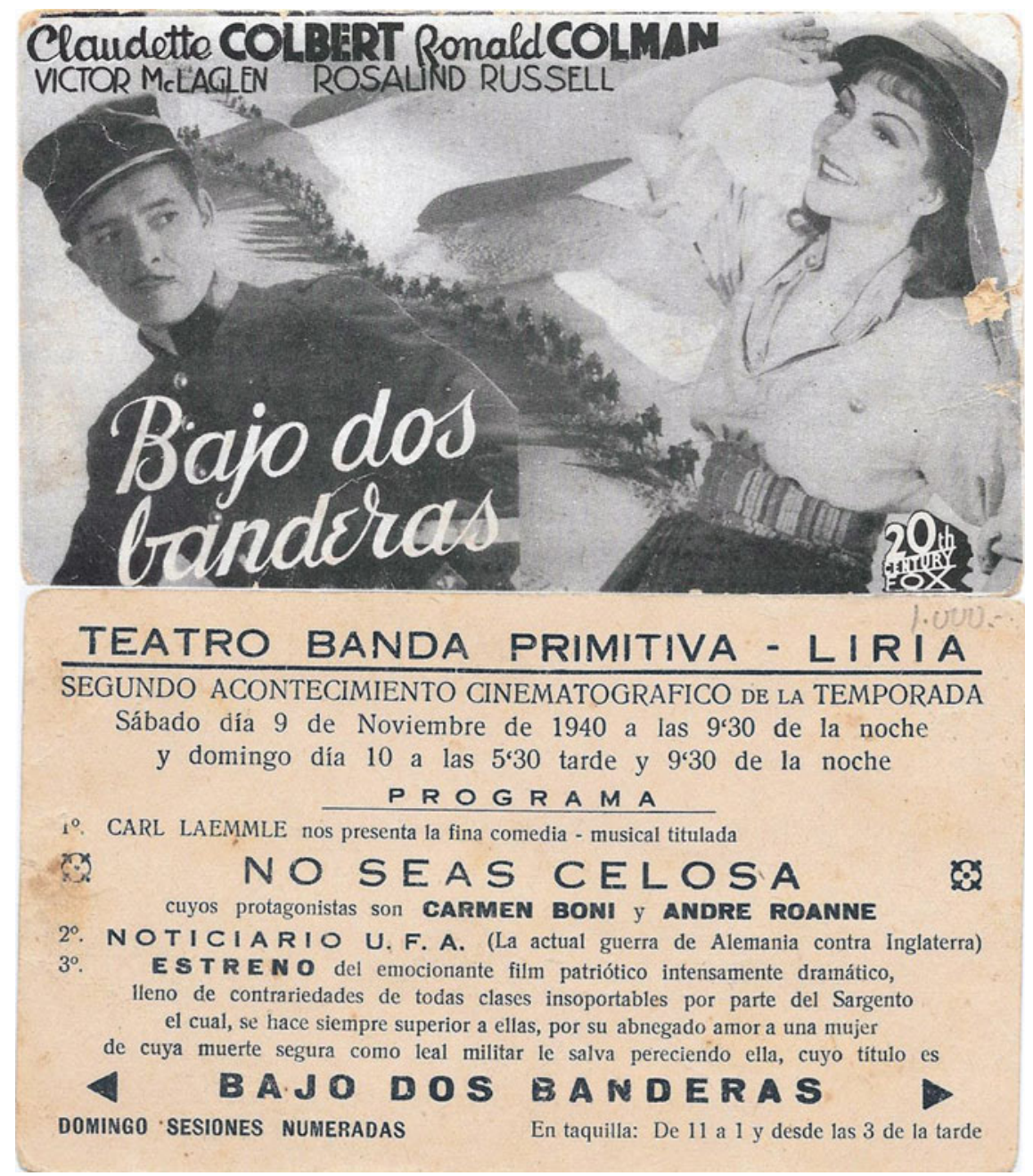

Image 10 Front and back of an Español Theatre's Film Programme (1940). Source Miguel Blat Ibáñez Collection, IVC Musical Documentation Centre, with permission

War. From 1936 to 1939, the social club became headquarters and dining room for the front line that was located on the famous XYZ line (Mallench Sanz \& Vicente Marco, 2018). In these years, the Banda was plundered, with instruments being sent to the front and to the different barracks for marches. Furthermore, in November 1937, the theatre suffered a fire that affected the extensive documentary and sheet music archive (Martín Montañés, 1994) (Informant 3).

At the end of the 1940s, the musical society managed to acquire the theatre (Image 11) and the social club premises (Banda Primitiva de Llíria, 1953a) (Image 12). Due to the condition of the theatre, the idea of improving all the society's 
Image 11 Entrance to the former Español Theatre (1950). Source Banda Primitiva de Llíria Archive, with permission

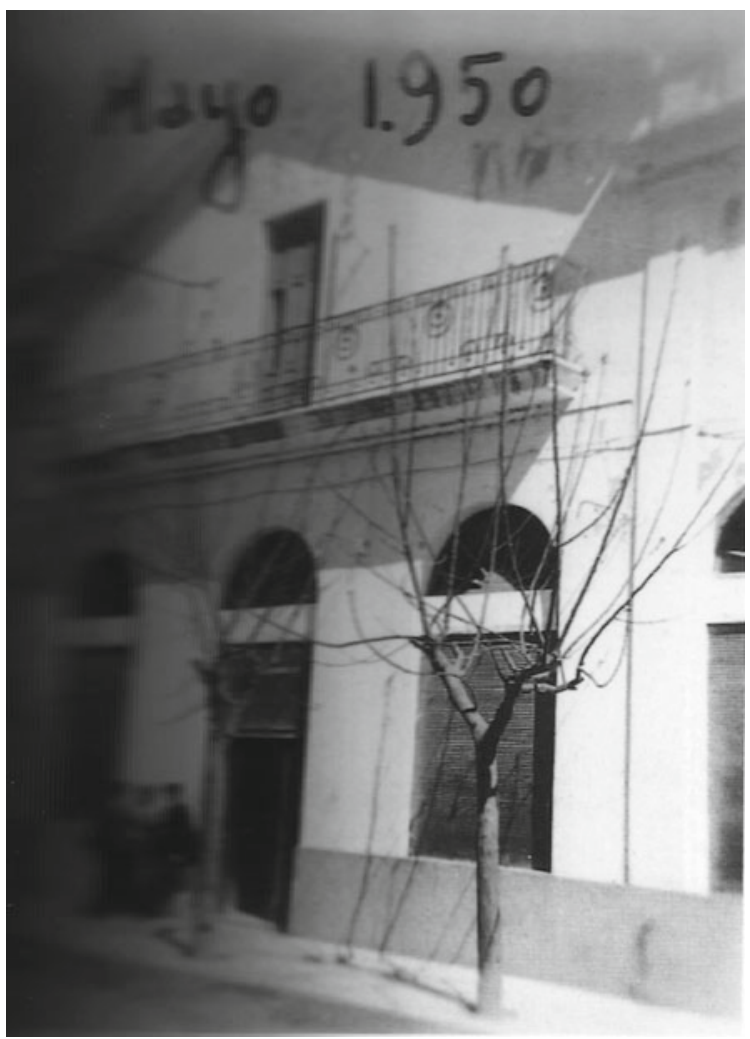

facilities was soon raised, either by refurbishing them or by demolishing them and then building a new theatre. The debate on how to proceed with the theatre continued throughout the decade, with the positions in favour of refurbishment and demolition clashing at the various members' meetings. In the end, the decision to demolish the theatre prevailed, a stance that was not supported by the Chairman of the society at the time (Banda Primitiva de Llíria, 1953b). Finally, in June 1950, the works to build the new theatre began (Martín Montañés, 1994).

As we have explained above, the project for the new theatre lasted for almost a decade. Initially, the society occupied the former theatre, which had a smaller capacity. To increase its capacity, representatives of the musical society entered into negotiations with the owners of neighbouring properties to purchase them. This fact gives us an insight into the scope of the society's ambitions at that time in their quest to build a benchmark theatre in the Valencian Region.

After the Society members' decision to choose the demolition and construction project, a decision was made to ask the Monte de Piedad savings bank in Valencia for a loan of one million pesetas backed by the properties of the members who were willing to put them up as collateral (Banda Primitiva de Llíria, 1953c). It is important to remember that, despite the post-war situation of Llíria at that time, which 
Image 12 Group of members together with the famous baritone Marcos Redondo, who gave several performances at the society, at the entrance to the social club in the former Español Theatre (1940s). Source Banda Primitiva de Llíria Archive, with permission

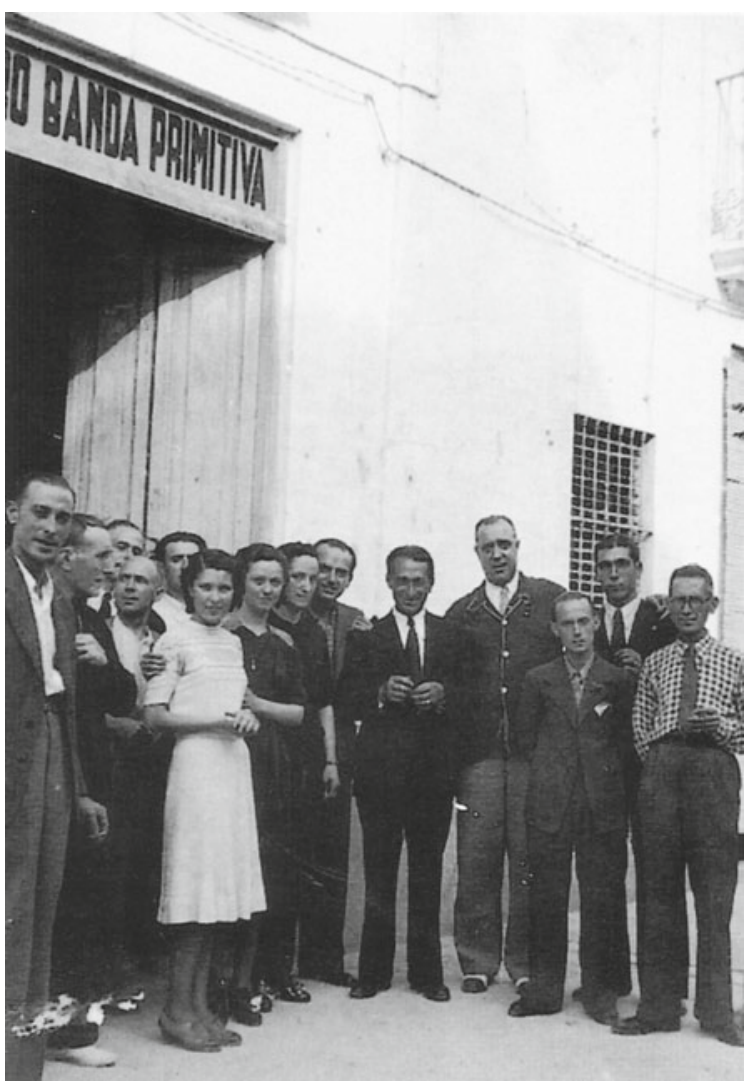

was a predominantly agricultural society that was dependent on ration cards until 1952 (Arco Blanco, 2006), and with a total population of less than 9,500 inhabitants (INE, 2020), the construction of a new theatre prevailed despite the difficulties. The social mass of the Banda Primitiva played a transcendental role in the construction of the building, as shown by the endorsement of the members and the selfless work that men and women linked to the Banda Primitiva put into the construction of the building, which meant huge cost reductions in the theatre's construction budget. Jobs that ranged from transporting materials with their own vehicles or carts, scaffolding and making fabrics meant important savings for the musical society. In addition to the direct cash contributions, different activities were also organised often involving women, such as the sale of lottery tickets and cakes to raise funds to help pay for the work. As a result of these contributions, it is estimated that the cost saving was over 650,000 pesetas in the construction of the new theatre (Banda Primitiva de Llíria, 1953a; Gasent-Blesa et al., 2019).

The theatre project was first assigned to Gimeno-Cruz, a renowned architect of the time who had worked in important towns such as Xativa, Gandia and Valencia. However, he did not finish the project because the society's Board decided to dispense 
with his services in 1950 due to issues and delays in the work. It is at this time that the figure of the prestigious architect Joaquín Rieta Síster (Banda Primitiva de Llíria, 1953d) became involved in the project. Rieta was the architect behind many other cultural buildings such as the Capitol and Tyris cinemas in Valencia (Herrera, 1983; IVAM and Generalitat Valenciana, 1998).

There are different hypotheses as to how Joaquín Rieta came into contact with the Banda Primitiva, though it was probably as a result of the relationship between him and Bartolomé Sabater, who had been the builder of some of Rieta's most important works in the city of Valencia. Sabater was a member of different society boards and was appointed by the Banda Primitiva to lead the construction of the new theatreconcert hall and the rest of the society's social club facilities, for over 1,200 people. The name of the architect Eduardo Alegre also appears in the documentation, who helped work against the clock (Gasent-Blesa et al., 2019).

Finally, Rieta was in charge of the work from around July 1950 until the theatre's opening on 23 September 1951, taking just 14 months to complete the project. As in the previous theatre, a broad range of cultural activities were offered including concerts, theatre and cinema (Image 13), attracting some of the most important European orchestras and soloists to the venue (Gasent-Blesa and Tándem Comunicación, 2019; Martín Montañés, 1994).

Subsequently, at the end of the twentieth century, both the theatre and the social club premises were renovated, and at the beginning of the twenty-first century, they were expanded to improve the quality of the facilities and offer more space for the music school including an auditorium with a hundred seats (the Malato Auditorium).

\section{Resilience of the Banda Primitiva de Llíria as Intangible Cultural Heritage}

The economic sustainability of this musical society is based on the diversity of its funding sources, including contributions from the local government, and income derived from the performances of the society's groups (mainly the band), its music school (Images 14 and 15), the fees paid by its members, the demand for music during festivities and even recent private sponsorship (Informant 2). In return for local government aid, the society performs various concerts and events in Llíria, as well as letting the town council use its theatre for different events, and other specific agreements with other public bodies.

The resilience capacity of the Banda Primitiva de Llíria comes largely from a diversified structure in which income is obtained from fees, public support, agreements and services. It is sustained mainly thanks "to the sense of identity" (Informant 2), and to the ability to symbolically represent the identity of the Edetans. These identity traits are what leads many of the members to undertake maintenance work for the Society, "the member is the one who maintains the band, when something is needed 
TeatIo BANDA PRIIIIIIIA - Liria

El cUadro artistico of esta entioad

el próximo Domingo 7 Junio de 1953 , a las $10^{\prime} 30$ de la noche

finallzara sus actuaciones de la temporada de invierno ton un Programa Extraordinario que completarád in COLOSAL FIN DE FIESTA 1. Se proyectará la interesante pelicula

$$
\text { C A S B A H }
$$

de ambiente marroqui, en la que se admiran sus más terribles fechorias.

2. ${ }^{\circ}$ ESTRENO de la comedia dramática en un acto y en prosa, que lleva por titulo

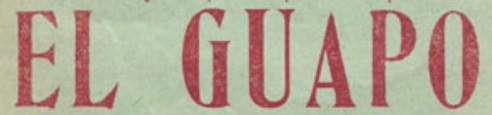

3. FIN DE FIESTA con arreglo al siguiente orden:

Paquita Viatela en "Como dos barquitos"

Juan Sintes " "Quien desprecia"

Victoria Gimenez " "La Chata en los toros" (poesia) Ramơn Devis " "Sombra del nublo"

Paqurts Vialela "La Zarza mora"

acompañado por el guitarrista de ésta (a) El. StRrano

Amparin Cervera en "Que bonito es el querer"

EL CONJUNTO DE VICETIPLES

y la pareja, Antrin Cotanda y Juan Llavata en

el paso-doble arrevistado el cual se titula

LA MAS PRECIOSA

NOTA: ¡Atención! ¡Atención! ¡Atención!

al programa del próximo miércoles dia 10 .

en el cual y a requerimientos de esta Entidad

se presentará el MAESTRO SOROZABAL

con su excelente Compañia Lirica poniendo en escena la popularisima zarzuela

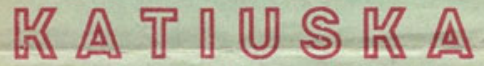

que será interpretada por el destacado y joven baritono de grandes EXXITOS

\section{Anton Navarro}

dirigiendo la orquesta el Maestro Sorozábal Completando el programa, un

- Grandioso Fin de Fiesta -

por el famoso baritono

PEDRO TEROL

y por las printipales y destacadas figaras de la tompailia

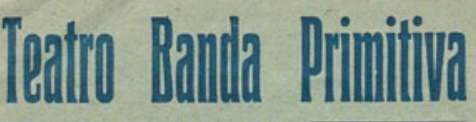

L I R I A

Jueves 22 de Septiembre de 1955

A las $10^{4} 45$ noche

Solemne conmemovación IV aniversario del nuevo local con la representación de la acreditada zarzuela

\section{La del Manojo de Rosas}

Por el Cuadro Artístico de la Sociedad tomando parte el famoso baritono tan querido de nuestro público

\section{ANTON NAVAREO}

\section{REPARTO}

Ascensión. ... . Pilar Alvares Bañuls

Clarita . . . . Srta. A Cervera

Doña Mariana . . * * V, Giménez

Doncella « C. Agustí

La Fisga . . . . Sra, C. Maicas

Joaquin .... A. NAVARRO

Ricardo ..... V. Albiach

Espasa. . . . F. Torres

Capó ... S Cortés

Don Pedro Botero . J. Morató

Don Daniel . . . . R. Martin

Un inglés J. Morató

Parroquiano $1^{\circ}$.... J. Cotanda

Parroquiano 2, . M. López

El del Mantecao . J. Jaubel

Un Camarero ... J Faubel

e

Breve discurso del Sr. Presidente

alusivo al acto $y$ a continuación

UHA PARTE DE CONCIERTO POR LA BANDA

bajo la dirección del maestro ESTEVE GALAN

MAGNIFICA PRESENTACION

NUTRIDA ORQUESTA

ALtorizado mayores de 16 años

PRECIOS POPULARES

Image 13 New theatre film programme, 1953 and New theatre programme (1955). Source Miguel Blat Ibáñez Collection, IVAC Musical Documentation Centre, with permission 
Image 14 Introduction of new technologies in the teaching methods of the Banda Primitiva de Llíria's music school. Source Banda Primitiva de Llíria Archive (2019), with permission

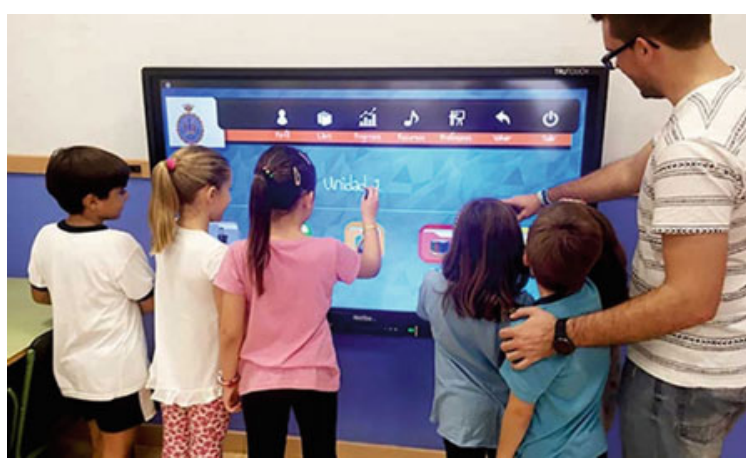

Image 15 Adapting teaching during the new health measures to prevent COVID-19, at the Banda Primitiva de Llíria's music school. Source Banda Primitiva de Llíria Archive (2020), with permission

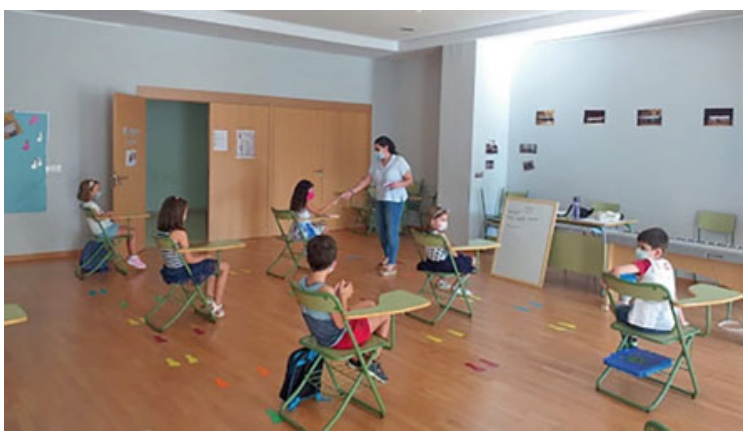

they are usually there to provide it" (Informant 2), since "it is a feeling to be part of the Clarín, a feeling as though it were your home" (Informant 1).

The Banda Primitiva's ability to mobilise society was clearly reflected in 2019, when the Ateneo Musical y de Enseñanza Banda Primitiva de Llíria celebrated its bicentenary. This opportunity was used to put together a programme of events that turned the Banda Primitiva into a cultural hub in the Valencian Region (Image 16). The programme included the participation of the society in some of the most important musical events in Spain, such as the Bankia Orchestra Contest (Image 17), the International Band Contest in the city of Valencia (Image 18) and the Pamplona International Festival of Bands (IFOB). Different events were also organised in the theatre-concert hall such as concerts, zarzuelas and plays, and performances were given by some of the best groups in the country including the Spanish Radio Television orchestra, the Music Group of the Inmemorial del Rey No. 1 Regiment and the Valencia Municipal Band. They featured some of the most important international musical figures on the current scene such as the Venezuelan trumpeter Pacho Flores, the Valencian clarinetist José Franch and the Dutch conductor Jan Cober.

The Society's activities during 2019 were not limited exclusively to the musical field, but also included a cycle of conferences-concerts, a photography contest and workshops, mainly for school students but also for people with functional diversity (Una Il·lusió col·lectiva. El Teatre de Joaquín Rieta, 2020). These workshops brought 


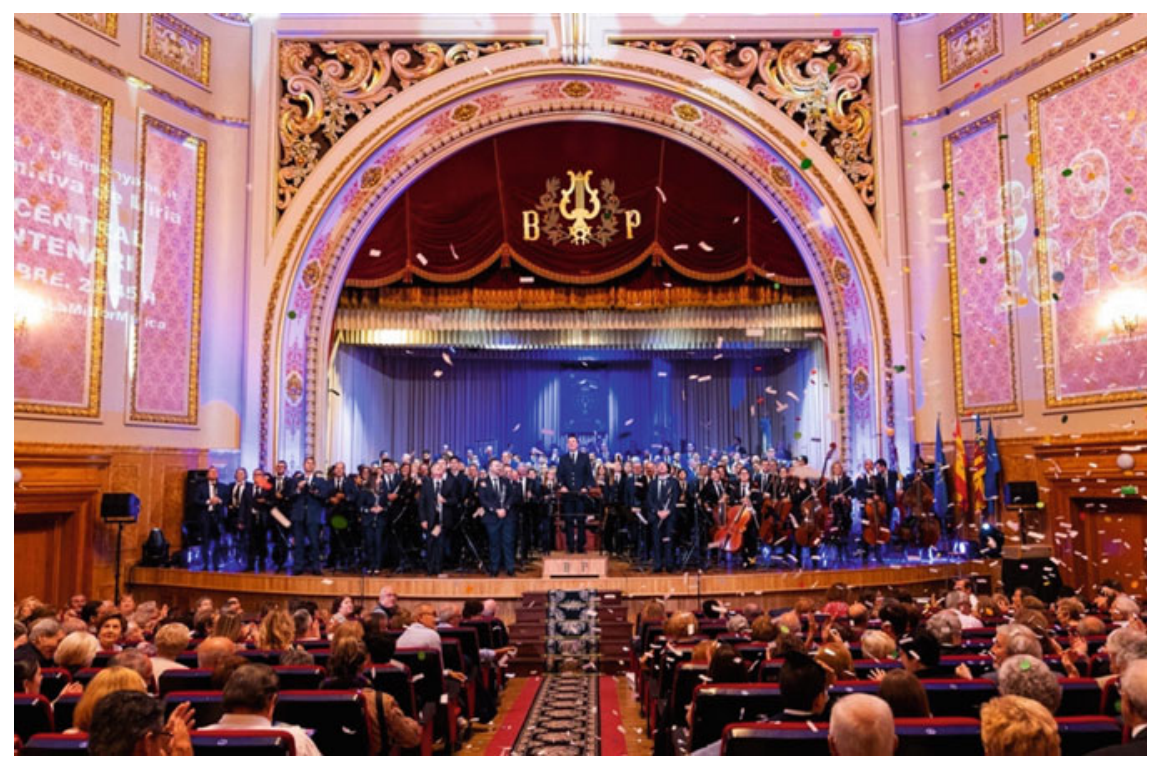

Image 16 Central event of the Banda Primitiva de Llíria's bicentenary celebrations. Source Banda Primitiva de Llíria Archive (2019), with permission

together more than 600 boys and girls, and adults with special needs and learning disabilities, who contributed their reflections on the social role of the Banda, as well as the analysis of its history and influence on the neighbourhood and town. At this point, the theatre-concert hall received special attention since it is one of the society's most impressive elements. Its construction took place in one of its peak moments as the nexus for the society of Llíria at the time. To commemorate this, an exhibition was organised in direct collaboration with researchers from the Universitat Politècnica de Valencia which brought a significant influx of visitors, including members of the Valencian Council of Culture, who held one of its plenary sessions at the theatre (Consell Valencià de Cultura, 2019). In addition, a documentary was produced in conjunction with the audiovisual company Tándem Comunicación which included interviews with people who worked altruistically in the construction of the theatre in 1950 and 1951 (Gasent-Blesa and Tándem Comunicación, 2019). Both public and private sponsors were obtained to fund these activities.

\section{Conclusions}

It is important to bear in mind that the phenomenon of music is an indicator of social change and an element that shapes different types of social identities (Asensi Silvestre, 2008). In the case of the Banda Primitiva de Llíria, also known as the Clarín, 


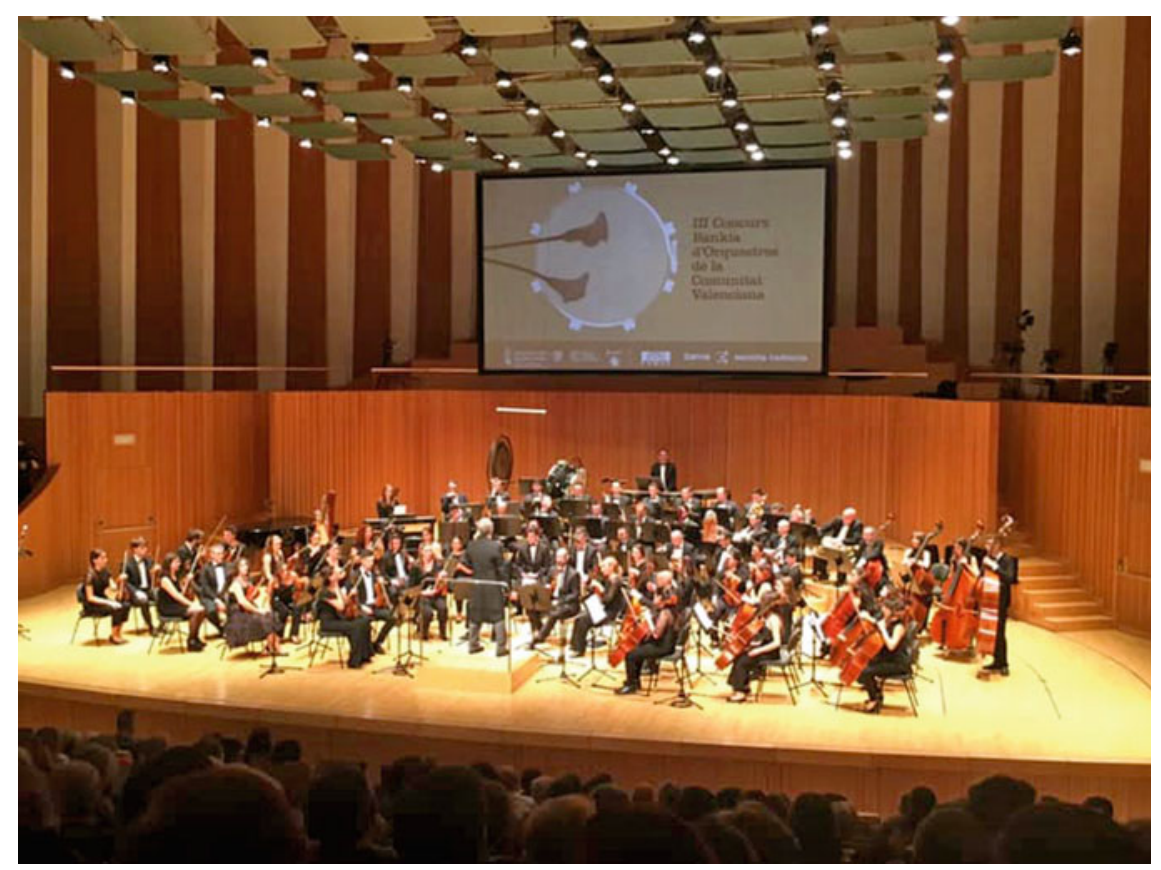

Image 17 Banda Primitiva de Llíria's symphonic orchestra, directed by its principal conductor Juan José Aguado, during the 3rd Bankia Orchestra Contest in the Valencian Region at the Palau de les Arts Opera House in Valencia (2019). Source Banda Primitiva de Llíria Archive, with permission

it is presented as "the great cultural victory of the popular classes" (Informant 2). It is important to remember that in the nineteenth century a high percentage of the rural population that made a living from agriculture was practically illiterate. However, they knew how to read sheet music and knew the main classical music composers and their works (Informant 2). This musical movement constituted an unprecedented cultural event, as it brought important opportunities to the town, as well as validating the collective identity of Llíria, "there is no other town that has such a strong sense of identity" (Informant 2). As Alfonso Aijón describes, in the 1980s in Llíria, the farmers went to the fields with their work tools and their instruments so they could practise during their breaks (Martínez Luengo, 2017).

This work aims to offer a framework for reflection that helps Valencians to identify with one of the most vivid expressions of our cultural heritage, and thus promote the search for safeguarding and dissemination strategies that generate the sustainability of these heritage resources in the current situation of cultural and creative uncertainty. 


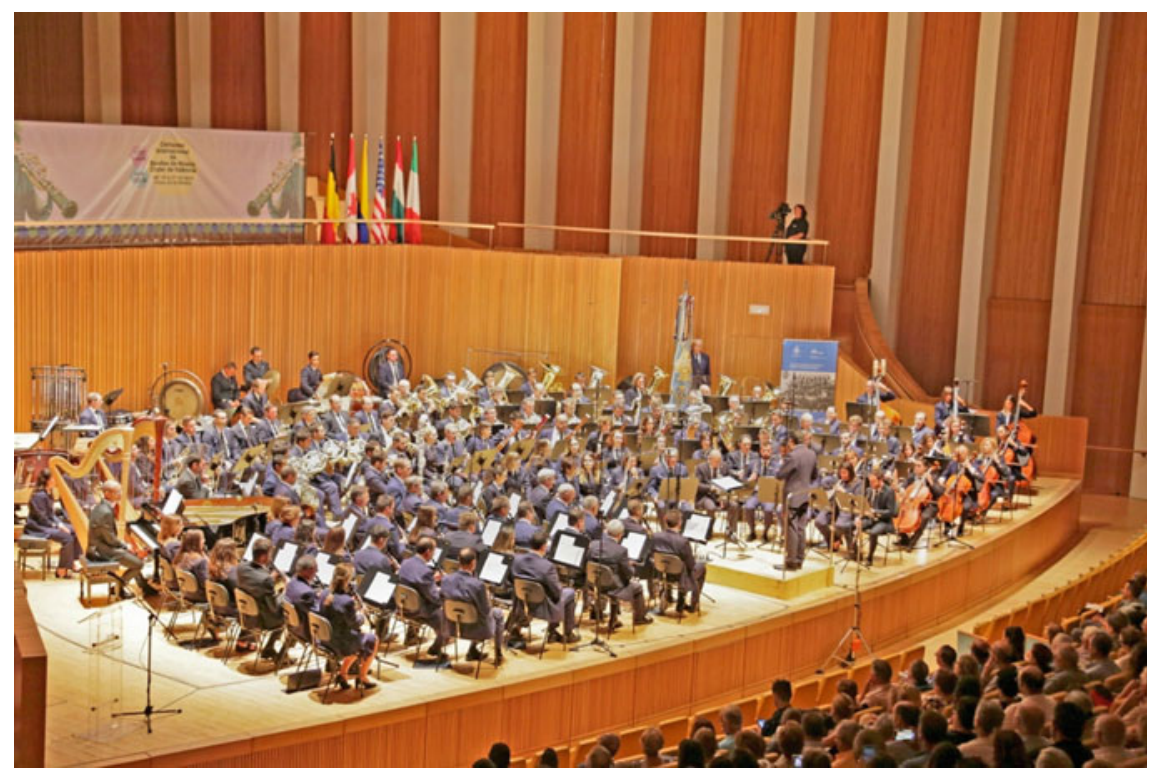

Image 18 Tribute concert in the International City of Valencia Music Bands Contest to mark the Banda Primitiva's bicentenary at the Palau de les Arts Reina Sofía Opera House in Valencia (2019), with permission. Source Banda Primitiva de Llíria Archive, with permission

Acknowledgements This work has been carried out within the framework of the collaboration agreement between the Sociedad Ateneo Musical y de Enseñanza Banda Primitiva de Llíria and the Universitat Politécnica de Valencia, to develop the project entitled "Identity, political and economic analysis of the Banda Primitiva de Llíria as a changing and living social process". We would especially like to thank the support and material provided by the Banda Primitiva de Llíria. We would also like to thank Vicent Arastey Pablo for his valuable documentary contribution to this work, Carmen Pérez Sabater and Marisa Pérez Sabater for the review of this work, and Ana Peñarrocha, for providing us with the image of the Band in California.

\section{Annexes}

Interviews:

- Informant 1: Llíria chronicler. Date of interview: 26 April 2019. Interview conducted by Anna Palmira Rodríguez Llorens.

- Informant 2: Llíria historian and member of the Banda Primitiva de Llíria. Date of interview: 26 April 2019. Interview conducted by Anna Palmira Rodríguez Llorens.

- Informant 3: Llíria Archive Management collaborator and member of the Banda Primitiva de Llíria. Date of interview: 26 April 2019. Interview conducted by Celia José Herrando. 
Archives:

- Banda Primitiva de Llíria Archive. Ateneo Musical y de Enseñanza Banda Primitiva de Llíria

- Miguel Blat Ibáñez Collection. IVC Music Documentation Centre, Valencian Government.

\section{References}

Arco Blanco, M. Á. d. (2006). «Morir de Hambre»: Autarquía, Escasez y Enfermedad En La España Del Primer Franquismo. Pasado y memoria (5), 241-258. http://hdl.handle.net/10045/ 5926 (February 13, 2021).

Asensi Silvestre, E. (2008). Sociabilidad e Identidad En Llíria: El Fenómeno Musical en un Municipio Valenciano (1822-1900). In I Encuentro de Jóvenes Investigadores En Historia Contemporánea de La AHC.

Astruells Moreno, S. (2017). El Certamen Internacional de Bandas de Música «Ciudad de Valencia» . Estudios bandisticos. Wind Band Studies, 1, 67-74. https://www.estudiosbandisticos.com/jou rnal/index.php/estudiosbandisticos/article/view/29 (February 13, 2021).

Ayuntamiento de Llíria. (2019). Llíria, Declarada Ciudad Creativa de La Música por la Unesco. Llíria City of music. http://www.lliria.es/es/report/liria-declarada-ciudad-creativa-musica-porunesco (February 9, 2021).

Ayuntamiento de Llíria. (2020a). La Ciudad. http://www.lliria.es/es/content/ciudad (January 21, 2021).

Ayuntamiento de Llíria. (2020b). Llíria City of music. http://www.lliria.es/es/content/ciudad-de-lamusica-0 (December 11, 2020).

Badenes Masó, G. (1992). Historia de La Música de La Comunidad Valenciana. El mercantil valenciano.

Banda Primitiva de Llíria. (1953a). Libro de Actas de 1948-1953. Archivo de la Banda Primitiva de Llíria (Acta 178).

Banda Primitiva de Llíria. (1953b). Libro de Actas de 1948-1953. Archivo de la Banda Primitiva de Llíria (Acta 204).

Banda Primitiva de Llíria. (1953c). Libro de Actas de 1948-1953. Archivo de la Banda Primitiva de Llíria (Acta 208).

Banda Primitiva de Llíria. (1953d). Libro de Actas de 1948-1953. Archivo de la Banda Primitiva de Llíria (Acta 219).

Banda Primitiva de Llíria. (2009a). Banda Primitiva de Llíria. http://www.bandaprimitiva.org/index. php/es/ (April 25, 2020).

Banda Primitiva de Llíria. (2009b). Historia - Banda Primitiva de Llíria. http://www.bandaprim itiva.es/index.php/es/banda-primitiva-cs/historia-cs (February 10, 2021).

Banda Primitiva de Llíria. (2009c). La Banda Primitiva de Llíria Presenta La Programación de Conciertos de Santa Cecília 2019 - Banda Primitiva de Llíria. http://www.bandaprimitiva.org/ index.php/es/sociedad1/noticias/678-programacion-stcecilia-2019 (April 25, 2020).

Bonet Rosado, H., Fortea Cervera, L., \& Ripollés Adelantado, E. (2014). Prehistory Museum of Valencia: Official Guide. http://www.museuprehistoriavalencia.es/web_mupreva_dedalo/public aciones/263/es (February 9, 2021).

Botella Nicolás, A. M. (2019). La Música Festera Como Patrimonio Inmaterial de la Humanidad. Revista eWali de investigación antropológica, histórica, cultural y/o social en el entorno Mediterráneo (1), 44-51. https://revistas.innovacionumh.es/index.php/eWali/article/view/355 (December 17, 2020). 
Cardiel, J. G. (2017). Las Flautistas de Iberia. Mujer y Transmisión de La Memoria Social En El Mundo Ibérico (Siglos III-I a.C.). Complutum, 28(1), 143-162. http://dx.doi.org/10.5209/CMPL. 58424 (February 9, 2021).

Casares Rodicio, E. (2006). Diccionario de La Música Valenciana I ICCMU.

Consell Valencià de Cultura. (2019). Ple CVC a la Banda Primitiva de Llíria-CVC.. https://cvc. gva.es/es/ple-cvc-a-la-banda-primitiva-de-lLlíria/ (February 10, 2021).

Cultural València. (2018). Tradición de Las Bandas de Música. BIC. https://cultural.valencia.es/es/ patrimonio-cultural/tradicion-de-las-bandas-de-musica-bic/ (December 10, 2020).

Diario de Valencia. (1917). Teatros. Biblioteca Virtual de Prensa Histórica (2112), 3. https:// prensahistorica.mcu.es/publicaciones/listar_numeros.do?busq_infoArticulos=true\&submit=Bus car\&busq_dia $=\& d e s c e n d e n t e=$ true $\&$ busq_idPublicacion $=1000771 \&$ busq_mes $=1 \&$ busq_anyo $=$ $1917 \&$ campoOrden $=$ fechaPublicacion\&posicion $=($ February 10, 2021 $)$.

Donat Zopo, J., \& Gascó Martínez, F. (1973). La Cova Del Cavall de Llíria (Valencia). Archivo de Prehistoria Levantina. http://www.museuprehistoriavalencia.es/web_mupreva_dedalo/public aciones/481/es (February 9, 2021).

Duran Martinez, J. (1995). Perfiles. Siluetas. Glosas de Mi Tierra. Ajuntament de Llíria.

España. (1926). Real Decreto-Ley de 9 de Agosto de 1926. Gaceta de Madrid (227, de 15 de agosto). https://www.boe.es/datos/pdfs/BOE/1926/227/A01026-01031.pdf (December 11, 2020).

España. (1933). Ley Del Patrimonio Artístico Español. Gaceta de Madrid (145 de 25 de mayo), 1393 a 1399.

España. (1953). Decreto de 12 de Junio de 1953 Por El Que Se Dictan Disposiciones Para Formalización Del Inventario Del Tesoro Artístico Nacional. Boletín Oficial del Estado (182, de 1 de julio), 3993 a 3994. https://www.boe.es/buscar/doc.php?id=BOE-A-1953-9108 (September 24, 2020).

España. (1961). Decreto 1938/1961, de 22 de Septiembre, Por El Que Se Crea El Servicio Nacional de Información Artística, Arqueológica y Etnológica. Boletín Oficial del Estado (254 de 24 de octubre), 15217 a 15218.

España. (1978). Constitución Española. Boletín Oficial del Estado (311 de 29 de diciembre). https:// www.boe.es/buscar/act.php?id=BOE-A-1978-31229 (December 11, 2020).

España. (1985). Ley 16/1985, de 25 de Junio, Del Patrimonio Histórico Español. Boletín Oficial del Estado (155, de 29 de junio). https://www.boe.es/buscar/act.php?id=BOE-A-1985-12534 (September 24, 2020).

España. (2007). Instrumento de Ratificación de la Convención para la Salvaguardia del Patrimonio Cultural Inmaterial, hecho en París el 3 de Noviembre de 2003. Boletín Oficial del Estado (31, de 5 de febrero), 5242 a 5248. https://www.boe.es/buscar/doc.php?id=BOE-A-2007-2382 (December $10,2020)$.

España. (2015). Ley 10/2015, de 26 de Mayo, Para La Salvaguardia Del Patrimonio Cultural Inmaterial. Boletín Oficial del Estado (126, de 27 de mayo). https://www.boe.es/buscar/act.php?id= BOE-A-2015-5794 (December 10, 2020).

FSMCV. (2021a). Las Sociedades Musicales de La Comunidad de Valenciana Son Declaradas Manifestación Representativa Del Patrimonio Cultural Inmaterial En España. Noticias. https:// fsmcv.org/es/actualidad/noticias/les-societats-musicals-de-la-comunitat-de-valenciana-sondeclarades-manifestacio-representativa-del-patrimoni-cultural-immaterial-a-espanya (April 1, 2021).

FSMCV. (2021b). Federació de Societats Musicals de La Comunidad Valenciana. https://fsmcv. org/es/ (February 5, 2021).

Gasent-Blesa, J. L., Alcocer, P., Oliver, P., Baró, J. L., Iborra, F., \& Guillén, I. (2019). Exposició. Una Il-lusió Col-lectiva. El Teatre de Joaquín Rieta. http://rieta.bandaprimitiva.es/index.php/val/ (April 25, 2020).

Gasent-Blesa, J. L., \& Tándem Comunicación. (2019). Vídeo-Documental Una Ilusión Colectiva Fragmento. España. https://www.youtube.com/watch?v=XIEWeyGg7TA (February 10, 2021). 
Generalitat Valenciana. (1998). Ley 4/1998, de 11 de Junio, Del Patrimonio Cultural Valenciano. DOGV (3267 de 18 de junio). https://www.boe.es/buscar/act.php?id=BOE-A-1998-17524\&p= 20170411\&tn=2 (December 10, 2020).

Generalitat Valenciana. (2011). Orden 1/2011, de 12 de Julio, de La Conselleria de Turismo, Cultura y Deporte, Por La Que Se Declara Bien Inmaterial de Relevancia Local La Tradición Musical Popular Valenciana Materializada Por Las Sociedades Musicales de La Comunidad Valenciana. [2011/8]. DOGV (6571 de 22 de juio). http://www.dogv.gva.es/portal/ficha_disposicion_pc.jsp? sig=008384/2011\&L=1 (December 10, 2020).

Generalitat Valenciana. (2012). Decreto 147/2012, de 5 de Octubre, Del Consell, por el que concede la Distinción de la Generalitat al Mérito Cultural a la Banda Primitiva de Llíria. [2012/9286]. DOGV (6878 de 8 de octubre). http://www.dogv.gva.es/datos/2012/10/08/pdf/2012_9286.pdf (February 10, 2021).

Generalitat Valenciana. (2018). Decreto 68/2018, de 25 de Mayo, Del Consell, Por El Que Se Declara Bien de Interés Cultural Inmaterial La Tradición Musical Popular Valenciana Materializada Por Las Sociedades Musicales de La Comunidad Valenciana. DOGV (8308 de 1 de junio). https:// www.dogv.gva.es/es/eli/es-vc/d/2018/05/25/68/ (December 10, 2020).

Hermosilla Pla, J. (2011a). Historia Contemporánea. In Llíria, Historia, Geografía y Arte: Nuestro Pasado y Presente (pp. 251-369). Facultat de Geografia i Història Universitat de València.

Hermosilla Pla, J. (2011b). Historia de La Música. In Llíria, Historia, Geografía y Arte: Nuestro Pasado y Presente (pp. 211-248). Facultat de Geografia i Història Universitat de València.

Hermosilla Pla, J. (2011c). Historia Medieval. In Llíria, Historia, Geografía y Arte: Nuestro Pasado y Presente (pp. 109-152). Facultat de Geografia i Història Universitat de València.

Hermosilla Pla, J. (2011d). Historia Moderna. In Llíria, Historia, Geografía y Arte: Nuestro Pasado y Presente (pp. 155-208). Facultat de Geografia i Història Universitat de València.

Hermosilla Pla, J. (2011e). Llíria Durante El Periodo Romano y La Antigüedad Tardía. In Llíria, Historia, Geografía y Arte: Nuestro Pasado y Presente (pp. 49-106). Facultat de Geografia i Història Universitat de València.

Herrera, J. M. (1983). Joaquín Rieta Sister, Arquitecto Valenciano: 1897-1982. Colegio Oficial de Arquitectos de Valencia.

INE. (2020). Valencia/València: Población Por Municipios y Sexo. Cifras oficiales de población de los municipios españoles: Revisión del Padrón Municipal. Resultados. https://www.ine.es/jax iT3/Datos.htm?t=2903\#!tabs-tabla (January 21, 2021).

IVAM and Generalitat Valenciana. (1998). La Ciudad Moderna: Arquitectura Racionalista En Valencia. Valencia.

Llimerá Dus, J. J. (2011). Asociacionismo: El Ateneo Musical y de Enseñanza, Banda Primitiva de Llíria. In Llíria, Historia, Geografía y Arte Nuestro Pasado y Presente (pp. 343-353).

Mallench Sanz, C., \& Vicente Marco, B. (2018). Línea XYZ. El Impenetrable Muro de Levante. Desperta Ferro: Contemporánea (27), 36-42.

Martín Montañés, R. (1994). Historia Músico-Social Del Ateneo Musical y de Enseñanza : Banda Primitiva de Llíria. https://www.musicaalallum.es/es/materiales/historia-banda-primitiva-de-lLl íria/ (February 9, 2021).

Martínez Luengo, J. (2017). Alfonso Aijón: 'No Hay Orquesta Importante Que No Tenga Solistas Españoles' I El Cultural. EL CULTURAL. https://elcultural.com/Alfonso-Aijon-No-hayorquesta-importante-que-no-tenga-solistas-espanoles (February 13, 2021).

Ministerio de Cultura y Deporte. (2011). Plan Nacional de Salvaguardia Del Patrimonio Cultural Inmaterial. http://www.culturaydeporte.gob.es/planes-nacionales/planes-nacionales/sal vaguardia-patrimonio-cultural-inmaterial.html (December 10, 2020).

Orden del Carmen (presumed). (1822). Libro de Deliberaciones de la Venerable Orden Tercera del Carmen de la Villa de Llíria. [Manuscrito] Archivo la iglesia de la Asunción de Nuestra Señora, hoja 9 vuelto, Llíria.

Orden Franciscana (presumed). (1821-1835). Libro de Entradas y Salidas del Convento de San Francisco (Llíria). [Libro de Cuenta y Razón o de lngresos] Archivo del Reino de Valencia, Libro 339 (1821-09-15-1835-08-14), Valencia. 
Pelechà, P., \& Francés, M. (2016). Documental "50 Aniversari 1r Premi de La Banda Primitiva a Kerkrade." YouTube. https://www.youtube.com/watch?v=bSu4wckOZgQ (February 10, 2021).

Pérez-Jorge, V. (1951). La Música En La Provincia Franciscana de Valencia.

Rausell Köster, P. (2013). Las Sociedades Musicales 2020. In III Congreso General de Sociedades Musicales 2013 Resumen Ejecutivo. http://www.uv.es/cursegsm/PDF/IIICSMCVRE.pdf (June 22, 2019).

Redacció ARA Multimèdia. (2013). Qui per Frà, Qui per Germà, Tot Lo Món Es Franciscà. ARA Multimèdia. https://www.aramultimedia.com/qui-per-fra-qui-per-germa-tot-lo-mon-es-fra ncisca-2 (February 13, 2021).

Rodríguez Lorenzo, G. A. (2014). The Banda Municipal de Música de Madrid [The Municipal Band of Madrid] (pp. 1-17).

Rosado, H. B., Parreño, C. M., \& Martín, A. M. (2008). Iron age landscape and rural habitat in the Edetan Territory, Iberia (4th-3rd Centuries BC). Journal of Mediterranean Archaeology, 21(2), 165-189. https://journal.equinoxpub.com/JMA/article/view/874 (February 9, 2021).

Sanchis Rodenes, E., \& Malato Ruiz, J. M. (2004). Josep M. Malato Ruiz: Un Il.Lustre Músic Tarragoní. Tarragona.

SGAE. (2020). Las Bandas de Música de La Comunidad Valenciana Serán Declaradas Patrimonio Cultural Inmaterial. SGAE. http://www.sgae.es/es-ES/SitePages/EstaPasandoDetalleAct ualidad.aspx?i=4451\&s=5 (December 10, 2020).

Tormo-Esteve, S. (2018). The Roman baths of Mura in Llíria (Valencia): Study applied to the thermal functionality of the Roman thermal complex - Dialnet. In I. Cabrera Fausto (Ed.), Reactive proactive architecture (pp. 372-377). UPV[Scientia]. https:/gdocu.upv.es/alfresco/service/api/node/ content/workspace/SpacesStore/ad88c844-156b-4743-889f-2123acbcaa84/6472.pdf?guest=true

Torres Castellano, M. (2006). Llíria, Cuna de Músicos. Ajuntament de Llíria.

UNESCO. (1989). Recomendación Sobre La Salvaguardia de La Cultura Tradicional y Popular. http://portal.unesco.org/es/ev.php-URL_ID=13141\&URL_DO=DO_TOPIC\&URL_ SECTION=201.html (April 11, 2020).

UNESCO. (1998). Resoluciones. In Actas de La Conferencia General. $29^{a}$ Reunión. París, 21 de Octubre - 12 de Noviembre de 1997 (pp. 1-140). https://unesdoc.unesco.org/ark:/48223/pf0000 110220_spa (December 11, 2020).

UNESCO. (2001). Proclamación de Las Obras Maestras Del Patrimonio Oral e Inmaterial de La Humanidad (2001-2005). https://ich.unesco.org/es/proclamacion-de-obras-maestras-00103 (September 24, 2020).

UNESCO. (2003). Convención Para La Salvaguardia Del Patrimonio Cultural Inmaterial. http://portal.unesco.org/es/ev.php-URL_ID=17716\&URL_DO=DO_TOPIC\&URL_SEC TION=201.html (April 11, 2020).

UNESCO. (2008). Las Listas del PCI y El Registro de Buenas Prácticas de Salvaguardia. https:// ich.unesco.org/es/listas (December 10, 2020).

UNESCO. (2019). \#WindowsOfMusicAndHope in Llíria, UNESCO Creative City of Music. https:// en.unesco.org/news/windowsofmusicandhope-1liria-unesco-creative-city-music (December 11, 2020).

UNESCO. (2020). Creative Cities. Creative Cities Network. https://en.unesco.org/creative-cities/ (December 17, 2020).

Uriel, D. (1946). Bosquejo Histórico de La Música En Llíria, Excluyendo Los Tiempos Actuales. Saitabi revista de la Facultat de Geografia i Història, 4(20-21), 95-109. 
Open Access This chapter is licensed under the terms of the Creative Commons Attribution 4.0 International License (http://creativecommons.org/licenses/by/4.0/), which permits use, sharing, adaptation, distribution and reproduction in any medium or format, as long as you give appropriate credit to the original author(s) and the source, provide a link to the Creative Commons license and indicate if changes were made.

The images or other third party material in this chapter are included in the chapter's Creative Commons license, unless indicated otherwise in a credit line to the material. If material is not included in the chapter's Creative Commons license and your intended use is not permitted by statutory regulation or exceeds the permitted use, you will need to obtain permission directly from the copyright holder.

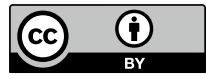

